\title{
REVIEW
}

\section{Our evolving conceptual model of the coastal eutrophication problem}

\author{
James E. Cloern* \\ US Geological Survey, MS496, 345 Middlefield Rd., Menlo Park, California 94025, USA
}

\begin{abstract}
A primary focus of coastal science during the past 3 decades has been the question: How does anthropogenic nutrient enrichment cause change in the structure or function of nearshore coastal ecosystems? This theme of environmental science is recent, so our conceptual model of the coastal eutrophication problem continues to change rapidly. In this review, I suggest that the early (Phase I) conceptual model was strongly influenced by limnologists, who began intense study of lake eutrophication by the 1960s. The Phase I model emphasized changing nutrient input as a signal, and responses to that signal as increased phytoplankton biomass and primary production, decomposition of phytoplanktonderived organic matter, and enhanced depletion of oxygen from bottom waters. Coastal research in recent decades has identified key differences in the responses of lakes and coastal-estuarine ecosystems to nutrient enrichment. The contemporary (Phase II) conceptual model reflects those differences and includes explicit recognition of (1) system-specific attributes that act as a filter to modulate the responses to enrichment (leading to large differences among estuarine-coastal systems in their sensitivity to nutrient enrichment); and (2) a complex suite of direct and indirect responses including linked changes in: water transparency, distribution of vascular plants and biomass of macroalgae, sediment biogeochemistry and nutrient cycling, nutrient ratios and their regulation of phytoplankton community composition, frequency of toxic/harmful algal blooms, habitat quality for metazoans, reproduction/growth/survival of pelagic and benthic invertebrates, and subtle changes such as shifts in the seasonality of ecosystem functions. Each aspect of the Phase II model is illustrated here with examples from coastal ecosystems around the world. In the last section of this review I present one vision of the next (Phase III) stage in the evolution of our conceptual model, organized around 5 questions that will guide coastal science in the early 21st century: (1) How do system-specific attributes constrain or amplify the responses of coastal ecosystems to nutrient enrichment? (2) How does nutrient enrichment interact with other stressors (toxic contaminants, fishing harvest, aquaculture, nonindigenous species, habitat loss, climate change, hydrologic manipulations) to change coastal ecosystems? (3) How are responses to multiple stressors linked? (4) How does human-induced change in the coastal zone impact the Earth system as habitat for humanity and other species? (5) How can a deeper scientific understanding of the coastal eutrophication problem be applied to develop tools for building strategies at ecosystem restoration or rehabilitation?
\end{abstract}

KEY WORDS: Coastal eutrophication · Nutrient enrichment $\cdot$ Estuaries $\cdot$ Nitrogen $\cdot$ Phosphorus $\cdot$ Coastal ecosystems

\section{INTRODUCTION}

By the end of the twentieth century one of our most important scientific accomplishments has been the explicit realization that the human population is changing the Earth system. Some of these changes are occurring at a remarkable rate. We know, with certainty, that human activities are changing land use, habitats, the chemistry of the Earth's atmosphere and water, rates and balance of biogeochemical processes, and diversity of life on the planet (e.g. Vitousek et al. 1997). One prominent mode of human disturbance has resulted from activities that 
mobilize the nutrient elements nitrogen and phosphorus through land clearing, production and applications of fertilizer, discharge of human waste, animal production, and combustion of fossil fuels (e.g. Nixon 1995). As a result of these activities, surface waters and ground waters throughout the developed world now have elevated concentrations of $\mathrm{N}$ and $\mathrm{P}$ compared to concentrations even in the middle of the 20th century. Our mobilization of $\mathrm{N}$ and $\mathrm{P}$ has accelerated the fluxes of these elements to coastal waters, and fertilization of coastal ecosystems is now a serious environmental problem because it stimulates plant growth and disrupts the balance between the production and metabolism of organic matter in the coastal zone.

Coastal eutrophication is a recently recognized phenomenon (Nixon 1995), and scientific investigation of this human disturbance has progressed for only a few decades, so our conceptual model of the problem is evolving rapidly. Here, I describe 2 phases in the evolution of our conceptual model of how nutrient enrichment disrupts coastal ecosystems, and then finish with a view to the future, suggesting critical questions that must be answered as we work to advance and broaden our understanding of this complex environmental problem. This examination of conceptual models was designed as a complement to the excellent general reviews of coastal eutrophication (e.g. Smetacek et al. 1991, Gray 1992, Vollenweider 1992, Heip 1995, Nixon 1995, Jørgensen \& Richardson 1996, National Research Council 2000).

\section{IN THE BEGINNING: THE FIRST CONCEPTUAL MODEL}

The time series in Fig. 1 show clear signals of elevated nitrate concentration in 3 rivers in different regions of North America and Europe. These trends of increasing $\mathrm{N}$ concentration are representative of changes in the nutrient ( $\mathrm{N}$ and $\mathrm{P}$ ) chemistry of rivers throughout the developed world, with many showing progressive increases that accelerated during the period $1960-1990$. The underlying mechanisms of these trends are well established (e.g. Puckett 1995, Jaworski et al. 1997, National Research Council 2000) and directly related to human activities that mobilize and accelerate the movement of $\mathrm{N}$ and $\mathrm{P}$ from the lithosphere to the hydrosphere. Our concern about this human disturbance was first motivated by the degradation of freshwater ecosystems by nutrient enrichment, and the study of lake-river eutrophication was a central focus of freshwater ecological and geochemical research by the 1960s. Nixon (1995) reminds us that this topic was not a focus of estuarine or coastal marine research then, so there was a lag of perhaps a decade or two before the problem of coastal eutrophication
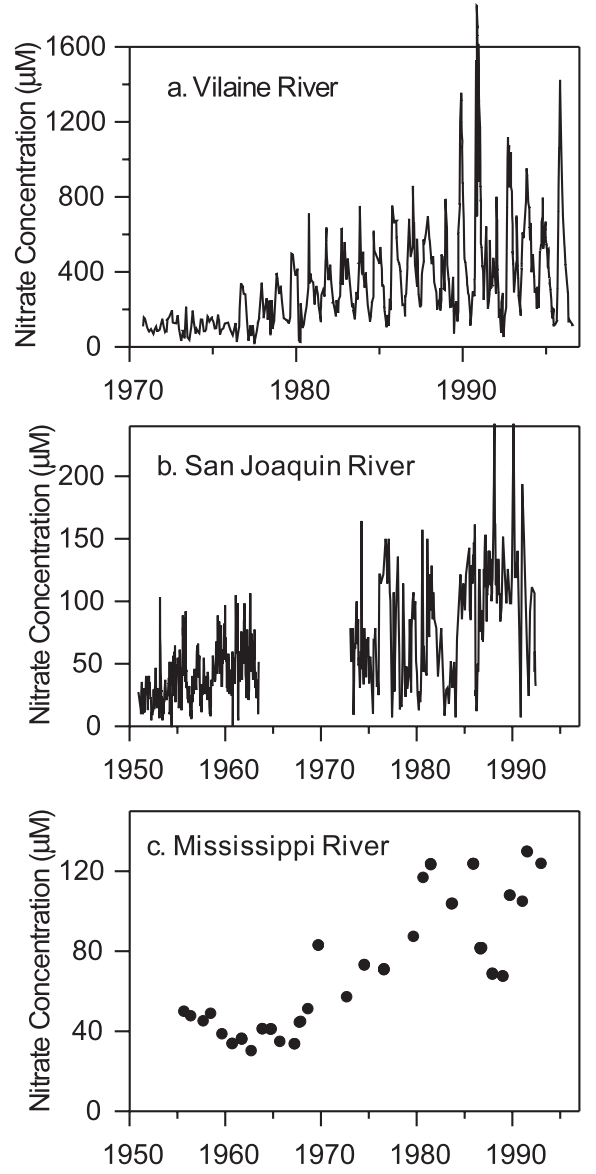

Fig. 1. Three examples showing decadal-scale trends of increasing nitrate concentration in rivers: (a) Vilaine River, France (redrawn from Moreau et al. 1998, Fig. 2); (b) San Joaquin River, US (data from Kratzer \& Shelton 1998, Fig. 40); (c) lower Mississippi River (redrawn from Rabalais et al. 1996, Fig. 4)

became established as a societal and scientific concern. It is natural, then, that the earliest conceptual model of coastal eutrophication was strongly influenced by the conceptual models developed first by limnologists. As we will see, there are fundamental differences in the system-level responses to nutrient enrichment in lakes compared to estuarine-coastal ecosystems.

One result of human enrichment of $\mathrm{N}$ and $\mathrm{P}$ in rivers is that the delivery of these elements to the coastal zone has increased proportionately. For example, Jaworski et al. (1997) estimate that human activities have increased $\mathrm{N}$ fluxes to coastal rivers of the northeastern United States 5 to 14 times above natural rates. Phosphorus loading to estuarine systems has increased 2- to 6 -fold since 1900 (Conley 2000). Among those (surprisingly few) estuaries and coastal marine ecosystems in which there have been sustained observational programs, most have revealed significant decadal-scale trends of increasing $\mathrm{N}$ and/or $\mathrm{P}$ availability. Four examples in Fig. 2 show that both $\mathrm{N}$ and $\mathrm{P}$ concentrations 

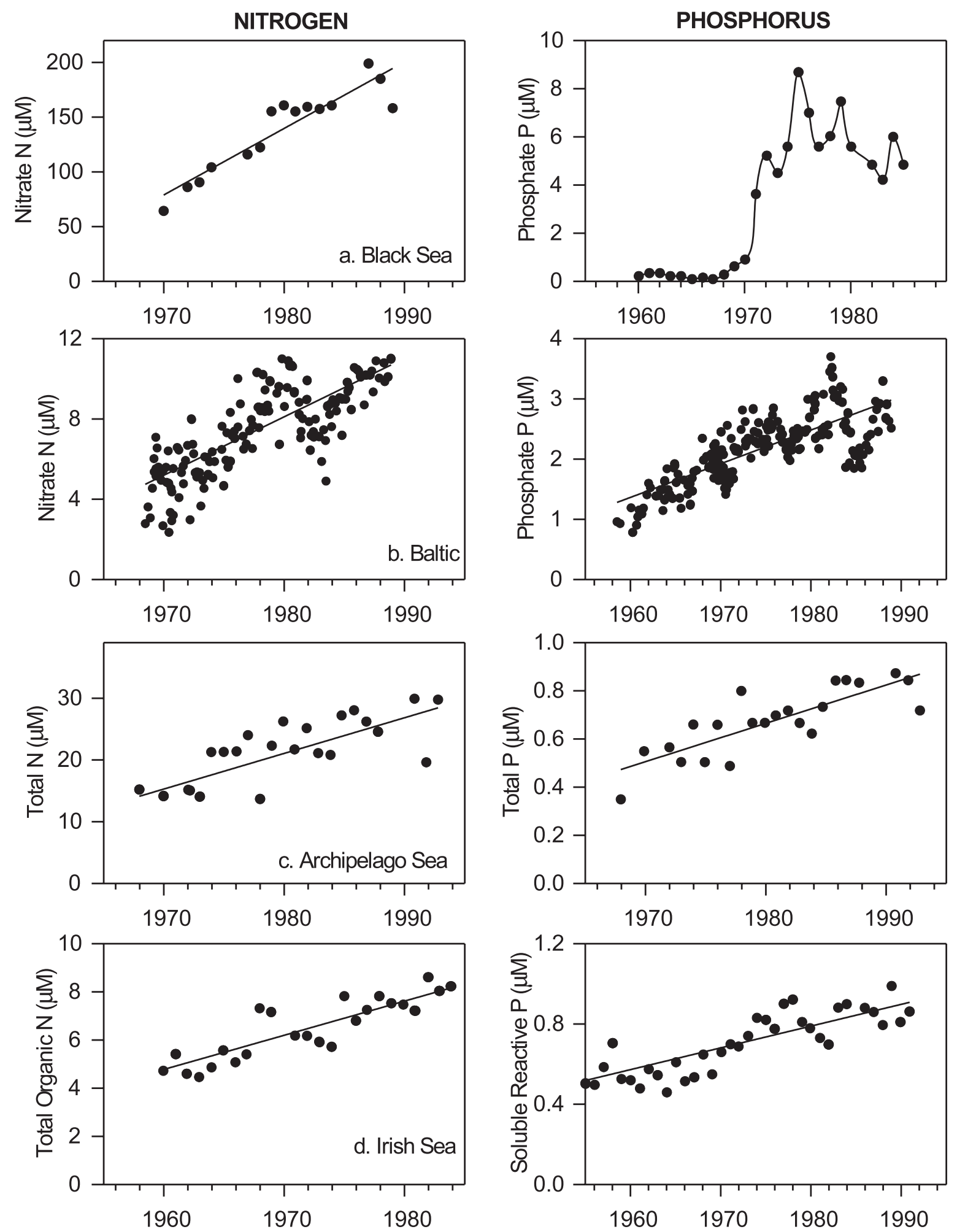

Fig. 2. Four examples showing decadal-scale trends of increasing $\mathrm{N}$ and $\mathrm{P}$ concentrations in coastal waters: (a) annual mean nitrate concentration in the lower Danube River and annual mean phosphate concentration in Romanian coastal waters of the Black Sea (redrawn from Mee 1992, Fig. 2); (b) nitrate and phosphate concentrations in bottom waters of the central Baltic Sea (redrawn from Nehring 1992, Fig. 5); (c) total N and total P concentrations in the outer Archipelago Sea, northern Baltic (redrawn from Bonsdorff et al. 1997b, Fig. 5); (d) median winter (January-February) concentrations of total organic $\mathrm{N}$ and soluble reactive $\mathrm{P}$ in the central Irish Sea (redrawn from Allen et al. 1998, Fig. 2) 
increased, by a factor of 2 or more, from the 1960s to 1990 in the Northwest Black Sea, central Baltic Sea, Archipelago Sea (northern Baltic), and in the Irish Sea. When examined as a whole, the existing nutrient records provide compelling evidence of rapid change in the fertility of coastal ecosystems over the last half of the 20th century. Retrospective analyses suggest that a 'first wave' of coastal eutrophication actually began in the 19th century when industrial activities enhanced the riverine delivery of $\mathrm{N}$ and $\mathrm{P}$ to coastal regions of western Europe (Billen et al. 1999). In their pristine state, these coastal ecosystems had $\mathrm{N}$ or P concentrations that were often low enough to limit the rate of plant biomass production and accumulation. Therefore, the central question considered here is: How does enhanced delivery of $\mathrm{N}$ or $\mathrm{P}$, with resulting elevations of $\mathrm{N}$ or $\mathrm{P}$ availability, change the biogeochemical functioning and biological community structure within estuarine and coastal waters? This central question is broader in scope than eutrophication, which is strictly defined as an increase in the supply rate of organic matter (Nixon 1995). In this review I use the word eutrophication in a more general sense to reference the myriad biogeochemical and ecological responses, either direct or indirect, to anthropogenic fertilization of ecosystems at the land-sea interface.

The limnologists addressed this question by constructing signal-response functions, where the signal was some measure of change in the availability of $\mathrm{P}$ (the most-limiting nutrient in freshwater) and the response was some measure of change in the productivity or biomass of the phytoplankton. This approach produced a set of empirical models built from measures of signals and responses in a large number of temperate-zone lakes. The classic example is the empirical model of Vollenweider (1976), reproduced in Fig. 3. Here, the mean phytoplankton biomass (chlorophyll a concentration) is described as a function of annual P loading, adjusted for differences in lake morphometry and hydraulic residence time. For this data set, the simple loadingplot model accounts for $75 \%$ of the variance of chlorophyll concentration. The strength of the correlation between this signal and response is impressive, and it shaped the conceptual models of lake eutrophication and became a basis for lake nutrient management (Schindler 1987).

Early work on coastal eutrophication was inspired by the Vollenweider-type approach. Although limnologists have explored many other aspects of the lake-eutrophication problem, the guiding conceptual model was strongly influenced by these empirical rela-

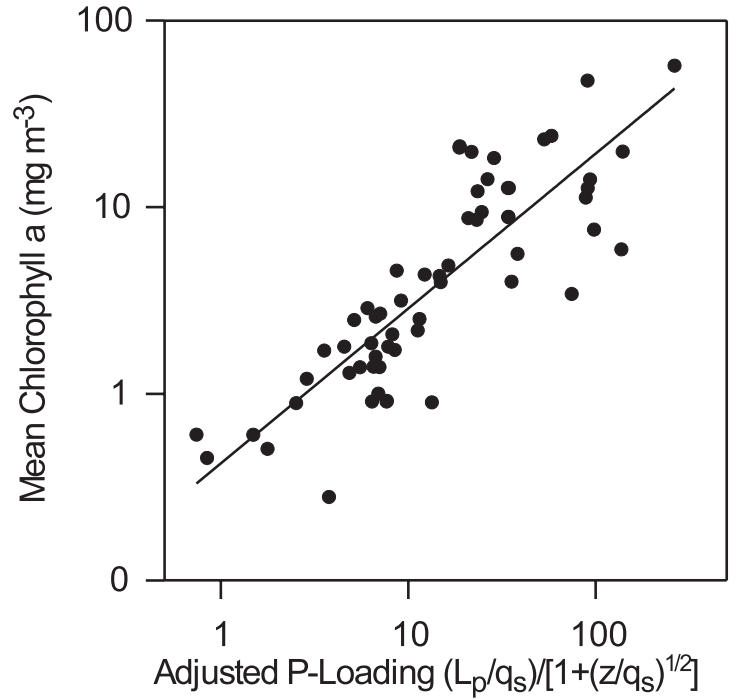

Fig. 3. Empirical model relating mean surface-water chlorophyll a concentration of lakes to the phosphorus loading $L_{\mathrm{p}}$ $\left(\mathrm{g} \mathrm{P} \mathrm{m} \mathrm{yr}^{-1}\right)$, adjusted for hydraulic loading $q_{\mathrm{s}}\left(\mathrm{m}^{3} \mathrm{~m}^{-2} \mathrm{yr}^{-1}\right)$ and mean depth $\mathrm{z}(\mathrm{m})$. Redrawn from Hecky \& Kilham (1988),

Fig. 7. Original source is Vollenweider (1976)

tionships and their emphasis on 1 signal and 1 set of closely related responses. We can depict this Phase I conceptual model with a simple schematic (Fig. 4) in which nutrient loading rate sets the rates of phytoplankton population growth and biomass accumulation. Stimulation of phytoplankton growth rate leads to an imbalance between the processes of algal production and consumption, followed by enhanced sedimentation of algal-derived organic matter, stimulation of microbial decomposition and oxygen consumption,
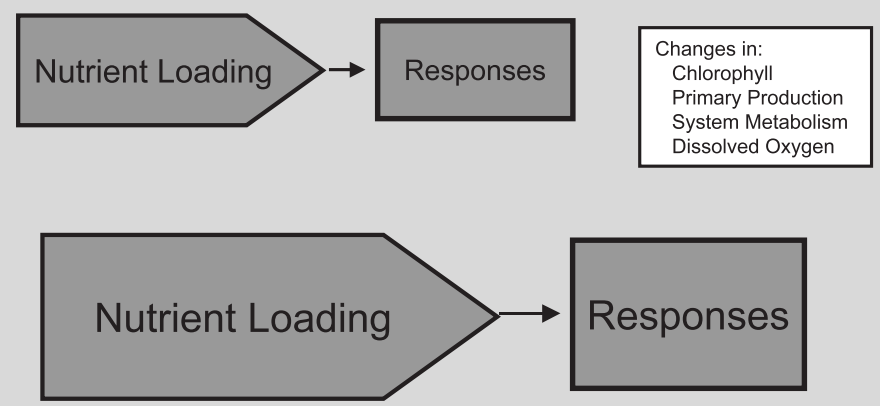

Fig. 4. Schematic diagram of the early (Phase I) conceptual model of coastal eutrophication, emphasizing the signal of nutrient loading and the responses associated with the stimulation of phytoplankton primary production and biomass accumulation. Magnitude of responses is proportional to nutrient loading 
and depletions of bottom-water oxygen after the onset of thermal stratification in spring or summer. The first studies of coastal eutrophication were designed around this conceptual model, with emphasis on measurements of the signal (as nutrient concentrations or fluxes) and the response (as measures of phytoplankton biomass, primary production, oxygen concentrations or consumption rates).

Freshwater and marine systems have different patterns of nutrient cycling, leading to differences in the relative importance of $\mathrm{N}$ and $\mathrm{P}$ as limiting elements. Phosphorus is generally considered the primary limiting element to system primary production in fresh water, and nitrogen is considered the primary limiting element in marine systems (Smith [1984] explains why this view is an oversimplification). Intense debate and scientific interest have motivated research to address the question: Which limiting element is most important in estuaries? The debate has extended to consider the question: What is the most appropriate definition of 'limitation'? (In the context of coastal eutrophication, Howarth [1988] defines nutrient limitation as 'the limitation on the potential rate of net primary production'). The general rule above is a result of differences in the biogeochemical cycling of $\mathrm{N}$ and $\mathrm{P}$ in fresh and marine waters (Oviatt et al. 1995, National Research Council 2000), including: (1) greater importance of nitrogen fixation (an $\mathrm{N}$ source) in freshwater systems, for reasons that are not fully understood (Howarth et al. 1995, 1999, Paerl et al. 1995); and (2) greater efficiency of sediments in freshwater systems at binding and sequestering $\mathrm{P}$ than sediments in marine systems (Caraco et al. 1990). Since McComb et al. (1981) and D'Elia et al. (1986) proposed that both $\mathrm{N}$ and $\mathrm{P}$ are important in estuaries, subsequent research has confirmed this with observations of $\mathrm{P}$ limitation during spring and $\mathrm{N}$ limitation during summer in estuaries such as the Gulf of Riga, Latvia, Roskilde Fjord, Denmark, Bay of Brest, France, and Delaware Bay, USA (Conley 2000). Our conceptual model of the relative importance of $\mathrm{N}$ and $\mathrm{P}$ is strongly biased by the predominance of study at temperate latitudes, so it does not apply directly to tropical marine systems that are more frequently P-limited (Downing et al. 1999).

Implicit in the lake-inspired conceptual model is the notion that a unit increase in the signal of nutrient loading will cause a unit increase in the set of phytoplankton-related responses (Fig. 4). This notion follows directly from the empirical model shown in Fig. 3. The first experimental work on coastal eutrophication employed mesocosms to measure system-level responses to varying treatments of nutrient $(\mathrm{N})$ enrichment (e.g. Oviatt et al. 1986). Results of the MERL mesocosm experiments fit the early conceptual model organized around the signal of nutrient delivery and the response of enhanced phytoplankton primary production or chlorophyll biomass (Nixon 1992). These experimental results, along with early compilations of measured responses and signals in coastal ecosystems, were generally consistent with the Phase I conceptual model. In the beginning, these results encouraged the notion that the lake eutrophication model might apply to estuarine-coastal ecosystems. However, as coastal scientists continued to work on this problem during the past 2 decades, we have made 2 kinds of observations that are inconsistent with the Phase I model. First, although it is possible to develop Vollenweider-type models for some sets of coastal lagoons (Boynton et al. 1996) and estuaries, these models are significantly different from the lake models. For example, Meeuwig (1999) developed empirical models that describe variability of phytoplankton biomass among 15 Canadian estuaries as functions of land use in the watersheds. These models show that the chlorophyll yield, per unit $\mathrm{N}$ delivery, is 10 times smaller than the mean chlorophyll yield derived from comparable lake models. This important observation raises the possibility that there are fundamental differences between lakes and estuaries in their transformations of exogenous $\mathrm{N}$ into algal biomass.

A second inconsistency has been revealed by recent compilations of signal-response measurements from a large number of estuaries, showing that there is only a weak general correlation between the signal of nutrient loading and the responses of phytoplankton biomass or primary production. The most comprehensive estuarine compilation so far is that of Borum (1996), reproduced here in Fig. 5. For these 51 estuaries, only $36 \%$ of the variance of phytoplankton primary production is correlated with the N-loading rate. This out-

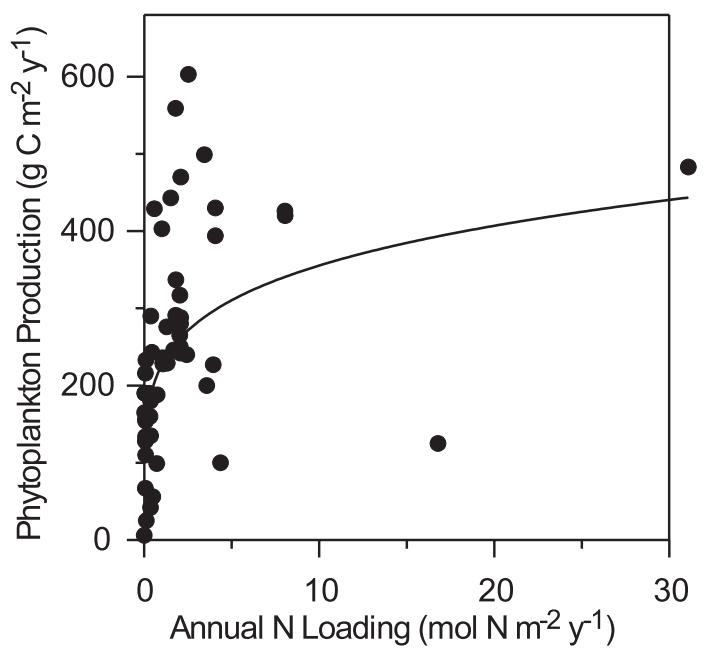

Fig. 5. Annual phytoplankton primary production versus annual $\mathrm{N}$ loading for coastal waters and mesocosms. Data from Borum (1996), Fig. 9.11. Fitted curve is the function $y=244+$ $175 \log (x)\left(r^{2}=0.36 ; n=51\right)$ 
come, coming from many different site-specific studies conducted over the past 2 to 3 decades, suggests that the Phase I conceptual model might not apply, at least in the context of understanding how the signal of changing nutrient input causes a general response of increased phytoplankton biomass or primary production in estuaries. Certainly there is a fundamental linkage between the processes of $\mathrm{N}$ delivery and the algal-based expressions of eutrophication. However, Borum's (1996) estuarine comparison suggests that $\mathrm{N}$-loading rate, alone, is a poor predictor of algal production rate. The problem must involve consideration of additional processes/factors.

The measurements in Fig. 5 show that there are some estuarine/coastal ecosystems with high N-loading rates but small rates of primary production, and others with relatively low loading rates but high primary production. These departures from the Phase I conceptual model are instructive, and we can illustrate them with measurements made in 2 nutrient-rich estuaries of the USA - Chesapeake Bay and San Francisco Bay. The annual loading rates of both nitrogen and phosphorus are higher in San Francisco Bay than in Chesapeake Bay: mean areal loadings of $\mathrm{N}$ are $1.47 \mathrm{~mol} \mathrm{~N} \mathrm{~m}^{-2} \mathrm{yr}^{-1}$ to the Maryland mainstem region of Chesapeake Bay (Boynton et al. 1995) and $1.96 \mathrm{~mol}$ $\mathrm{N} \mathrm{m}^{-2} \mathrm{yr}^{-1}$ to San Francisco Bay (D. H. Peterson; http//sfbay.wr.usgs.gov/ resmith/nput/nput.html). In the mesohaline region of Chesapeake Bay, winter DIN concentration approaches $100 \mu \mathrm{M}$, and this stock becomes depleted from the surface layer in summer
(Fig. 6). Near-surface dissolved inorganic phosphorus (DIP) concentrations are above $0.5 \mu \mathrm{M}$ in winter and then these also become depleted from the surface layer in spring/summer. The nutrient-enriched Chesapeake Bay supports very high standing stocks of phytoplankton (mean surface chlorophyll a of $13.6 \mathrm{mg} \mathrm{m}^{-3}$ in 1997; Fig. 6); annual primary production is $>400 \mathrm{~g} \mathrm{C} \mathrm{m}^{-2} \mathrm{yr}^{-1}$ (Malone et al. 1996). As a result of this high production and the subsequent deposition of algal biomass under stratified conditions, the bottom waters of Chesapeake Bay become hypoxic or anoxic in summer (Fig. 6). For the Chesapeake Bay estuary, nutrient-stimulated primary production and associated depletions of dissolved oxygen are high-priority environmental concerns among the local public and scientific community (Smith et al. 1992).

The 2 adjacent panels in Fig. 6 show comparable series from the mesohaline region of northern San Francisco Bay, where there are no analogous responses to the signal of nutrient enrichment. In the mesohaline San Francisco Bay, DIP concentrations are about 10 times higher than in the mesohaline Chesapeake Bay, and mean DIN concentrations are comparable and never fall to levels that limit phytoplankton growth. However, mean phytoplankton biomass in the mesohaline San Francisco Bay was only $2.7 \mathrm{mg} \mathrm{chl} a$ $\mathrm{m}^{-3}$ in 1997 (Fig. 6), and phytoplankton primary production is only $20 \mathrm{~g} \mathrm{C} \mathrm{m}^{-2} \mathrm{yr}^{-1}$ (Alpine \& Cloern 1992), about 20 times lower than in Chesapeake Bay. Although San Francisco Bay has higher loading rates of $\mathrm{N}$ (and P) than Chesapeake Bay, the bottom waters of
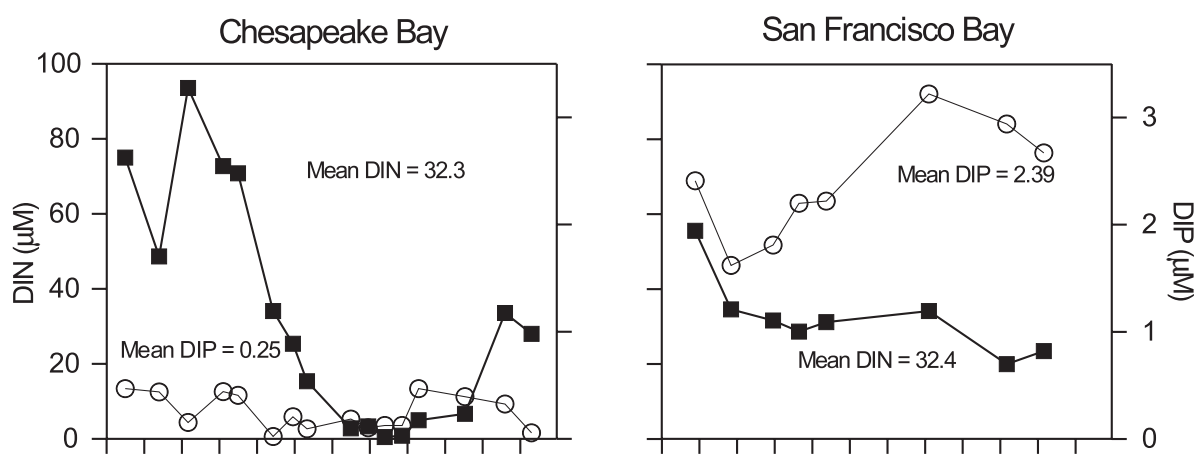

Fig. 6. Seasonal changes in waterquality constituents of the mesohaline Chesapeake Bay and northern San Francisco Bay for the year 1997. Upper panels show monthly measurements of dissolved inorganic $\mathrm{N}$ (DIN) and $\mathrm{P}$
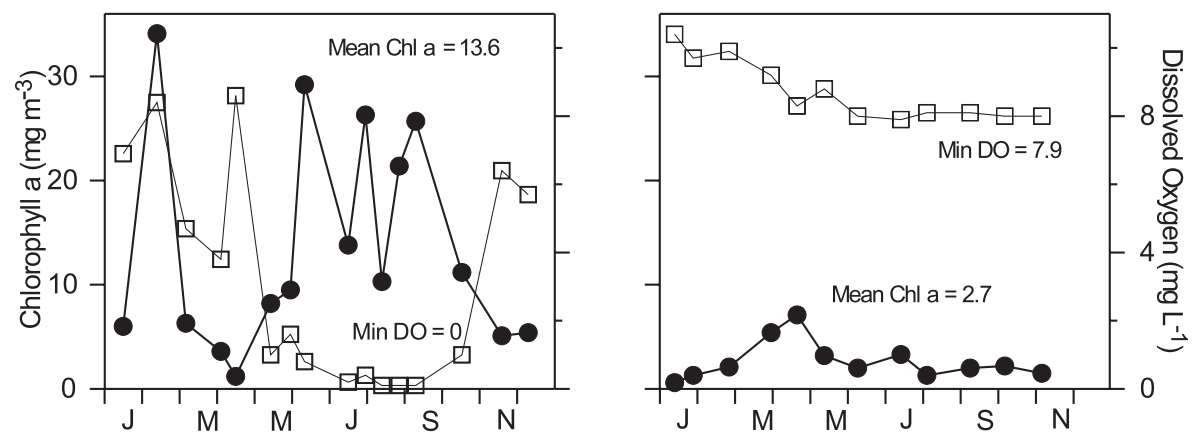
(DIP) in surface waters; bottom panels show near-surface chlorophyll a concentration and dissolved oxygen (DO) concentration in bottom waters. Data are from the Chesapeake Bay Program Monitoring station 3.3C (http:// www.chesapeakebay.nte/data) and the US Geological Survey Station 9 in northern San Francisco Bay (http://sfbay.wr.usgs. gov/access/wqdata) 
San Francisco Bay never approach hypoxia (Fig. 6). As a result, eutrophication is not a high-priority concern for the San Francisco Bay public. This contrast in algal biomass, primary production and bottom-water oxygen concentrations shows that there can be very large differences among estuaries in the rates or pathways through which exogenous nutrients are converted into algal biomass. Those differences strongly shape public concern and political priorities for managing coastal resources.

This realization is an important advancement in our scientific understanding of coastal eutrophication, and it suggests that we have advanced the science beyond the simple Phase I conceptual model of 1-signal and 1-response. Where, now, do we stand?

\section{RECENT ADVANCES AND THEIR CONTRIBUTIONS TO THE CONTEMPORARY CONCEPTUAL MODEL}

One of the most valuable approaches available to the limnological community in its study of lake eutrophication was the use of whole-ecosystem experiments in which systemic responses could be followed in experimental lakes subjected to different treatments of nutrient loading (Schindler 1987). Analogous experimentation at the scale of whole ecosystems has not been possible in the study of estuarine-coastal eutrophication (Nixon et al. 1986), so much of our understanding of coastal eutrophication has come from the collection and interpretation of time series of observations over the decades when nutrient concentrations have been elevated. Since the 1970 s, when the problem of nutrient enrichment has become a focal point of estuarinecoastal science, we have collected series of either new or historic observations, and used these to patch together an emerging new concept of how anthropogenic nutrient enrichment causes change in the coastal zone. Most of these time series come from only a few coastal regions of the world (e.g. Baltic Sea, coastal North Sea, Adriatic Sea, Black Sea, Chesapeake Bay, northern Gulf of Mexico), so our view of the problem is strongly biased by observations from these systems. Although individual time series may not provide convincing evidence of disturbance, the full suite of observations collected over the last half of the 20th century provides compelling evidence that some estuarine-coastal ecosystems have been and are being changed by enhanced inputs of nitrogen or phosphorus. In this section I present some examples to illustrate the modes of change we have detected through observational series, and then I use these examples to build a schematic representation of the current (Phase II) conceptual model of coastal eutrophication.

\section{Phytoplankton biomass and primary production}

We began with the concept that, since algal growth rates are often naturally limited by the availability of $\mathrm{N}$ or $\mathrm{P}$, then fertilization of estuarine-coastal waters with these elements will stimulate the growth, biomass accumulation, and primary production of the phytoplankton community. Although this seems to be a straightforward and easily tested idea, there are very few time series documenting clear trends of change in phytoplankton biomass coincident with trends of increasing nutrient concentrations. Three examples are shown in Fig. 7, as series of chlorophyll a measurements in the Irish Sea and Dutch Wadden Sea and as changes in the decade-mean chlorophyll a concentra-
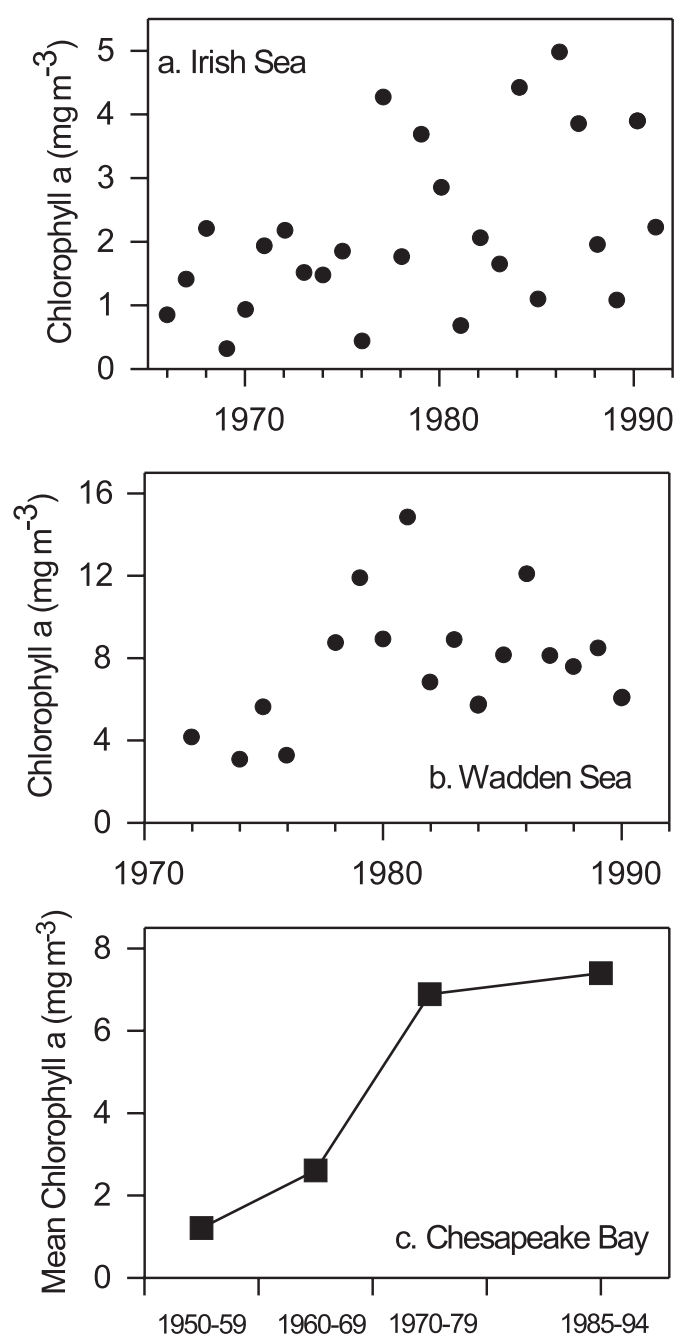

Fig. 7. Three examples showing trends of increasing phytoplankton biomass (annual- or decade-mean chlorophyll a concentration) in coastal ecosystems: (a) central Irish Sea (redrawn from Allen et al. 1998, Fig. 2); (b) Dutch Wadden Sea at Marsdiep (redrawn from Cadée 1992, Fig. 4); (c) lower Chesapeake Bay (Harding \& Perry 1997, Table 1) 
tions in the lower Chesapeake Bay. These series are all consistent with the first conceptual model of 1 general linkage between nutrients and phytoplankton biomass. However, there are comparable series (e.g. from San Francisco Bay [Alpine \& Cloern 1992], Ythan Estuary, Scotland [Balls et al. 1995], Bay of Brest [Le Pape et al. 1996]) that show no trend of increasing phytoplankton biomass, even during decades of increasing nutrient concentrations. So, the available long-term records of chlorophyll measurement are consistent with Borum's (1996) analysis showing intersystem differences in the linkage between the signal of nutrient increase and the response of increased phytoplankton biomass.

There are even fewer long-term records of primary production, but the 4 examples in Fig. 8 show trends of increased phytoplankton primary production in the northern Adriatic, Belt Sea, Wadden Sea, and in Danish coastal waters (Kattegat). Other than these 4 records, it is difficult to find series that document clear increases in phytoplankton primary production. There are, however, surrogate measures and perhaps the most useful come from the sedimentary record. An example is Fig. 9, showing depth profiles of organic carbon content in sediment cores taken in Chesapeake Bay. Although there has been no program to measure directly the changes in primary production in Chesapeake Bay since the first half of this century, the core profiles of organic carbon show progressive increase over time, consistent with the hypothesis that primary production has increased since the beginning of this century. More recent analyses of cores from Chesapeake Bay have used biogenic silica and lipids as source-specific biomarkers to confirm that the enhanced accumulation of carbon in the sediments is a result of increased inputs of algal-derived organic matter (Zimmerman \& Canuel 2000). Metabolism of algal-derived organic matter, both within the sediments and on the sediment surface, consumes oxygen and there are time series of dissolved oxygen measurements that provide further surrogate records of increased system production. Examples from Kiel Bay, the Kattegat, and Swedish coastal waters are shown in Fig. 10. Similar records have been established for other enriched coastal waters that are persistently stratified in summer, such as the northern Adriatic Sea (Justić et al. 1987).

\section{Responses in the sediments}

The core record of sediment organic carbon in Chesapeake Bay (Fig. 9) reminds us that the pelagic and benthic compartments of shallow marine ecosystems are tightly connected, so responses to nutrient
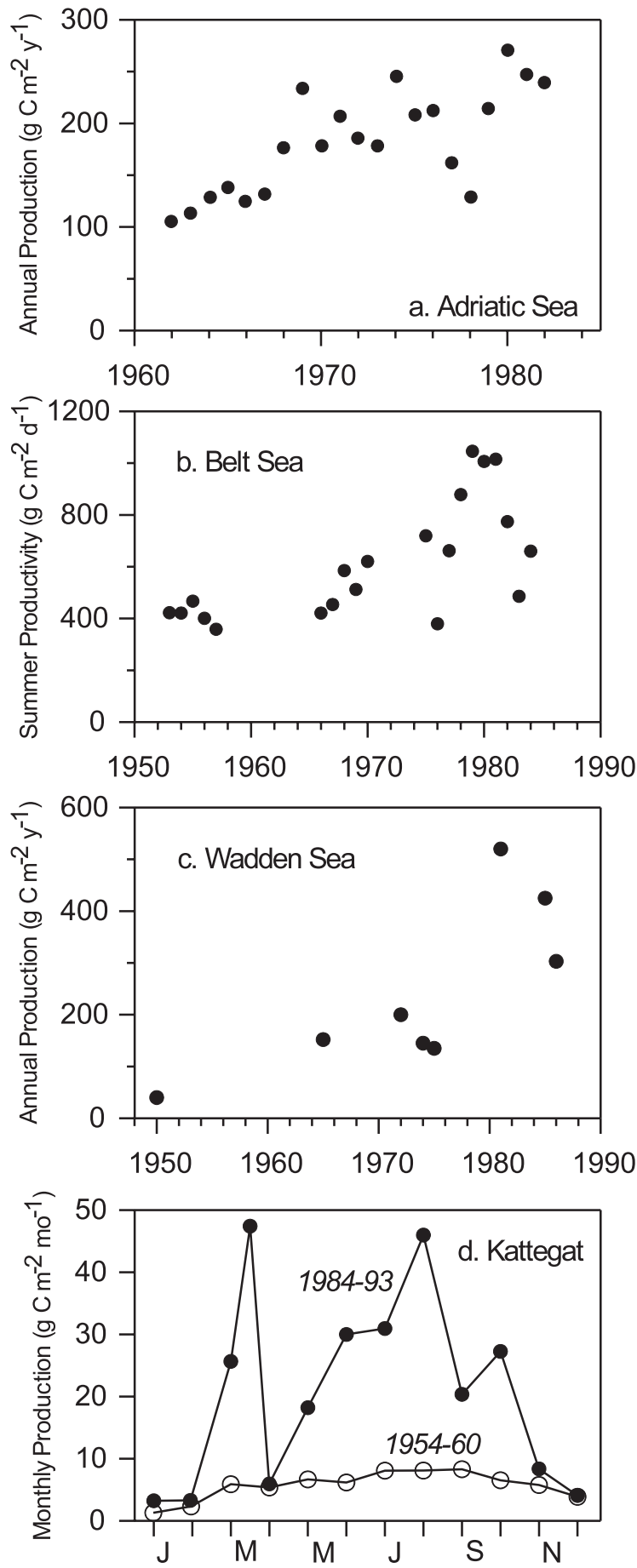

Fig. 8. Four examples showing decadal-scale increases in phytoplankton primary production in coastal waters: (a) annual primary production in Kaštela Bay, northern Adriatic Sea [redrawn from Šolic et al. 1997, Fig. 1); (b) daily mean summer primary productivity at Halskov Rev, Belt Sea (redrawn from Rydberg et al. 1991, Fig. 4b); (c) annual primary production in the Dutch Wadden Sea at Marsdiep (from the compilation of de Jonge 1990, Table 2); (d) mean monthly primary production in the southern Kattegat, comparing mean annual cycles for the periods 1954 to 1960 and 1984 to 1993 (redrawn from Richardson 1996, Fig. 5.11) 


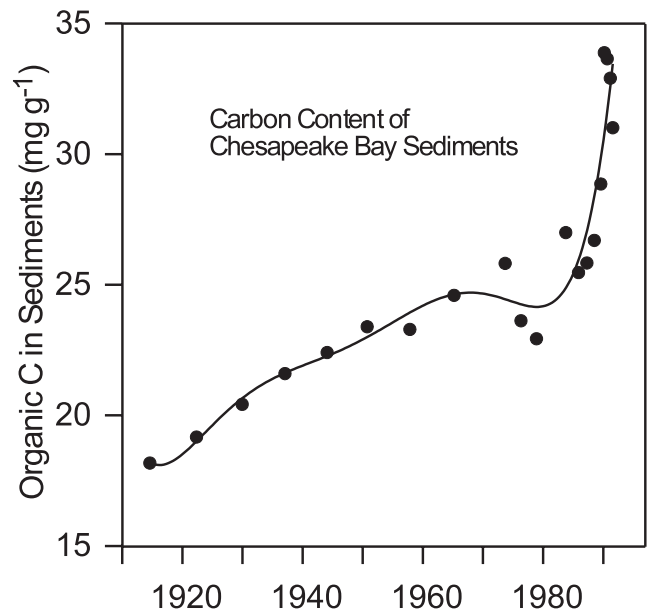

Fig. 9. History of organic $\mathrm{C}$ content of sediments in the mesohaline Chesapeake Bay, constructed from cores (redrawn from Cornwell et al. 1996, Fig. 6, core Hi)

enrichment can be seen as changes in the benthos. Much (25 to $50 \%$ ) of the organic $\mathrm{C}, \mathrm{N}$ and P produced by phytoplankton sinks to the benthos where it is mineralized by aerobic and anaerobic processes (Jørgensen 1996). The deposition rate of organic matter influences the depth of the oxic-anoxic interface within sediments, as well as the oxygen concentration in water above the sediments. When the supply rate of organic matter increases in response to nutrient enrichment, benthic microbial metabolism is stimulated and causes dramatic changes in sediment chemistry, nutrient release, and rates of oxygen consumption. In his review of the benthos response, Jørgensen (1996) concludes that 'the sediments and the benthic communities are, therefore, the most sensitive parts of the coastal ecosystem to eutrophication and hypoxia'. This sensitivity is reflected as a shift from aerobic to anaerobic metabolism, including stimulation of sulfate reduction and then accumulation of metal sulfides and $\mathrm{H}_{2} \mathrm{~S}$ in sediment pore waters. These changes can be recorded in the sediments and reconstructed from cores: shifts in sulfide mineralogy indicate that the bottom waters of Chesapeake Bay became more reducing around 1940 (Cooper \& Brush 1991, Zimmerman \& Canuel 2000). As sediments become more reducing, the phosphate bound to iron and manganese oxides can be released, so a feedback mechanism exists to enhance the sediment supply of $P$ to the water column when bottom waters become anoxic. Feedbacks between oxygen dynamics and nitrogen cycling also exist: nitrification is inhibited by hypoxia, so the loss of nitrogen to denitrification can be limited by the supply rate of nitrate. This feedback mechanism increases the efficiency of $\mathrm{N}$ retention as coastal systems move toward hypoxia (Kemp et al. 1990). Our conceptual model has therefore broadened to include explicit recognition of these microbial and geochemical responses in the sediments that result from the tight coupling between the pelagic and benthic compartments.

\section{Responses of other biota}

Perhaps the most important direct response to nutrient enrichment is change in the balance of selective forces that shape plant communities, including progressive selection for fast-growing algae (phytoplankton, microphytobenthos, ephemeral macroalgae) that are best adapted to high-nutrient conditions, at the expense of slower-growing vascular plants and perennial macroalgae that are best adapted to low-nutrient environments (Duarte 1995, Borum 1996). Well-known
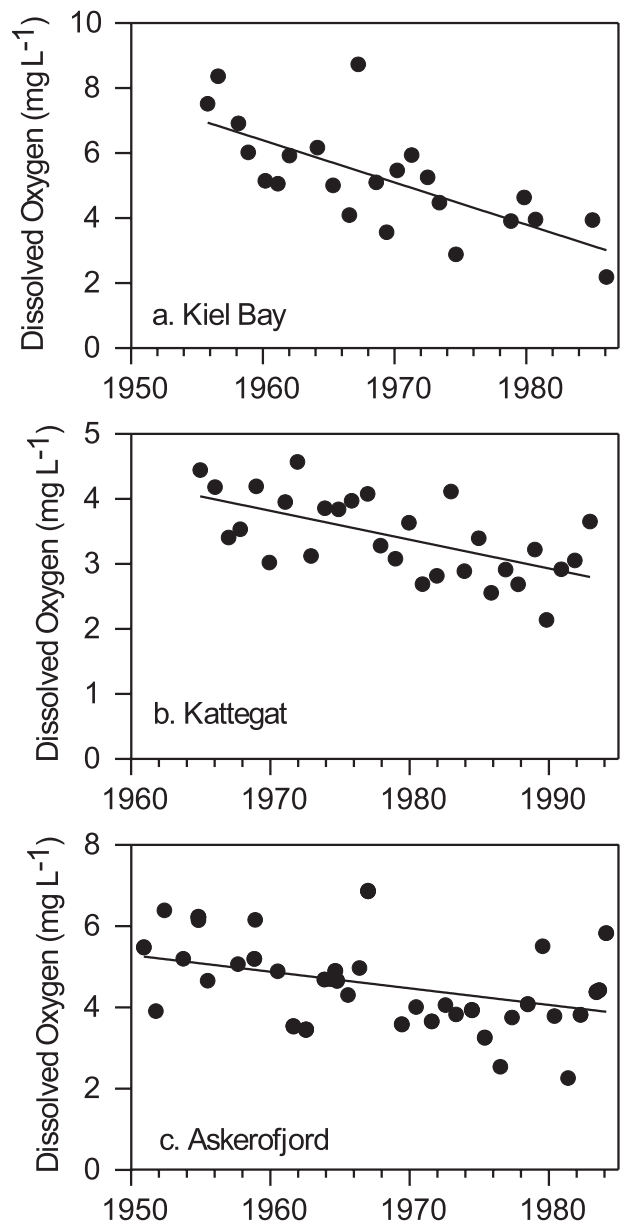

Fig. 10. Three examples showing decadal-scale trends of decreasing dissolved oxygen concentrations in bottom waters of coastal ecosystems: (a) Kiel Bay (redrawn from Funen County Council 1991, Fig. 5.6.8); (b) southern Kattegat (redrawn from Christensen 1998, Fig. 2.2); (c) annual minimum DO concentrations in the Askeröfjord, Sweden (redrawn from Rosenberg 1990, Fig. 3) 
manifestations of enrichment include massive accumulations of macroalgae in Tunis and Venice Lagoons (Sfriso et al. 1993), Saint Brieuc Bay and other open coastal systems in France (Menesguen 1992), Waquoit Bay and other urbanized embayments in the northeastern US (Valiela et al. 1997), and the Peel Harvey estuary in western Australia (McComb et al. 1981). Perhaps the best quantitative record of change in a littoral habitat is Cadée's (1984) surveillance of microphytobenthos biomass and primary production in the western Dutch Wadden Sea (Fig. 11). Both records show significant positive trends from 1968 to 1981, and Cadée (1984) interprets these trends as responses to nutrient enrichment.

As phytoplankton biomass increases, water transparency decreases proportionately and the reduced availability of light energy (e.g. Fig. 12) can become an indirect response that limits habitat for benthic plants. Submerged vascular plants have declined in Chesapeake Bay since the 1950s (Fig. 13a), and proposed mechanisms include decreased transparency associated with elevated phytoplankton biomass and other stresses, such as enhanced epiphyte growth, related to nutrient enrichment (Orth \& Moore 1983). Responses to algal bloom events, such as the persistent brown tides of Laguna Madre, include rapid declines in the abundance of seagrasses (Fig. 13b). The direct linkage between nutrient enrichment and vascular plant abundance is evident from Denmark's national estuarine
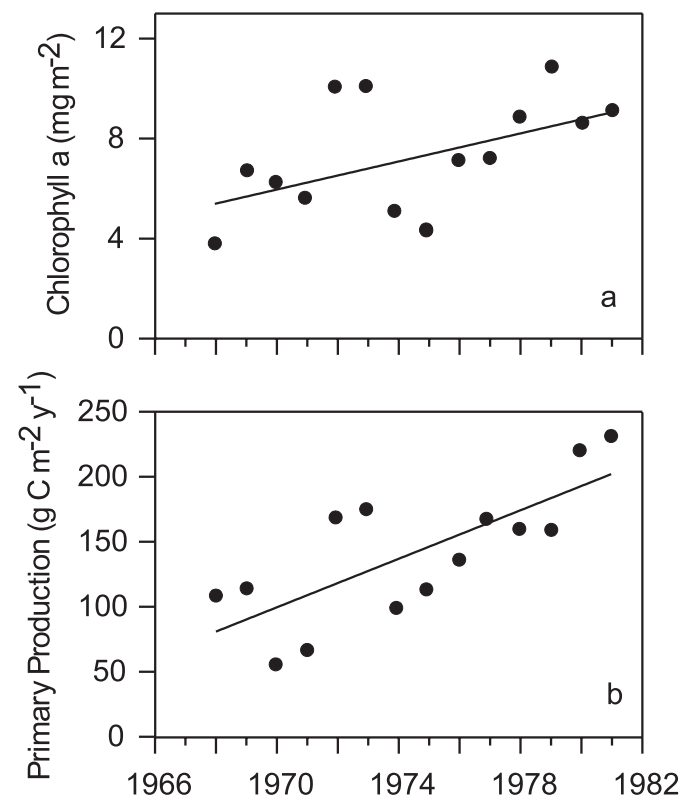

Fig. 11. Trends of increasing (a) biomass (chlorophyll a) and (b) primary production of microphytobenthos on a tidal flat in the western Dutch Wadden Sea (redrawn from Cadée 1984, Fig. 2)

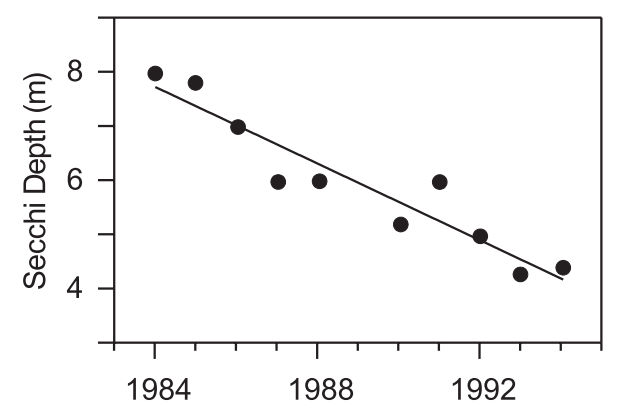

Fig. 12. Example of a trend of decreasing water transparency (winter Secchi depth) in the Åland archipelago, northern Baltic Sea (redrawn from Bonsdorff et al. 1997a, Fig. 3)

monitoring program, showing a strong inverse relationship between eelgrass habitat and nitrogen concentration in the overlying water (Fig. 13c). The depth limit of eelgrass growth in Danish estuaries is now only about $2.5 \mathrm{~m}$, half the growth habitat at the beginning of the 20th century (Rask et al. 1999). Habitat availability to perennial macroalgae also shrinks when water transparency declines: the depth distribution of Fucus vesiculosus decreased in the Baltic from $11.5 \mathrm{~m}$ in the 1940s to $8.5 \mathrm{~m}$ in the 1980s (Kautsky et al. 1986), an era when Secchi-depth transparency declined at a rate of $0.05 \mathrm{~m} \mathrm{yr}^{-1}$ (Sandén \& Håkansson 1996). Other direct and indirect responses to enrichment act as selective forces to change plant communities, including the toxicity of ammonium to eelgrass (Zostera marina: van Katwijk et al. 1997), and depletion of dissolved silicon (see below) which may be a contributing factor to the global declines of seagrasses (Herman et al. 1996).

Borum (1996) suggests that 'the most important effect of nutrient enrichment on primary producers in shallow coastal areas is to induce qualitative changes in ... the balance among autotrophic components from dominance of perennial macroalgae and seagrasses toward dominance of ephemeral macroalgae and pelagic microalgae.' These shifts in plant communities are profound changes in habitat quality for animals (Valiela et al. 1992, Weaver et al. 1997). Excessive macroalgal growth can lead to reduced diversity of marine invertebrates, analogous to responses to excessive phytoplankton growth: the scallop (Argopecten irradians) harvest virtually disappeared from the enriched zones of Waquoit Bay when seagrasses were replaced by macroalgae (Valiela et al. 1992). In shallow sublittoral or intertidal habitats, biomass accumulations of attached or drift macroalgae cause changes in bed roughness and trapping of fine-grained sediments and reduced survival of invertebrate recruits, exclusion of some deposit-feeding and suspensionfeeding invertebrates such as amphipods and spionid 

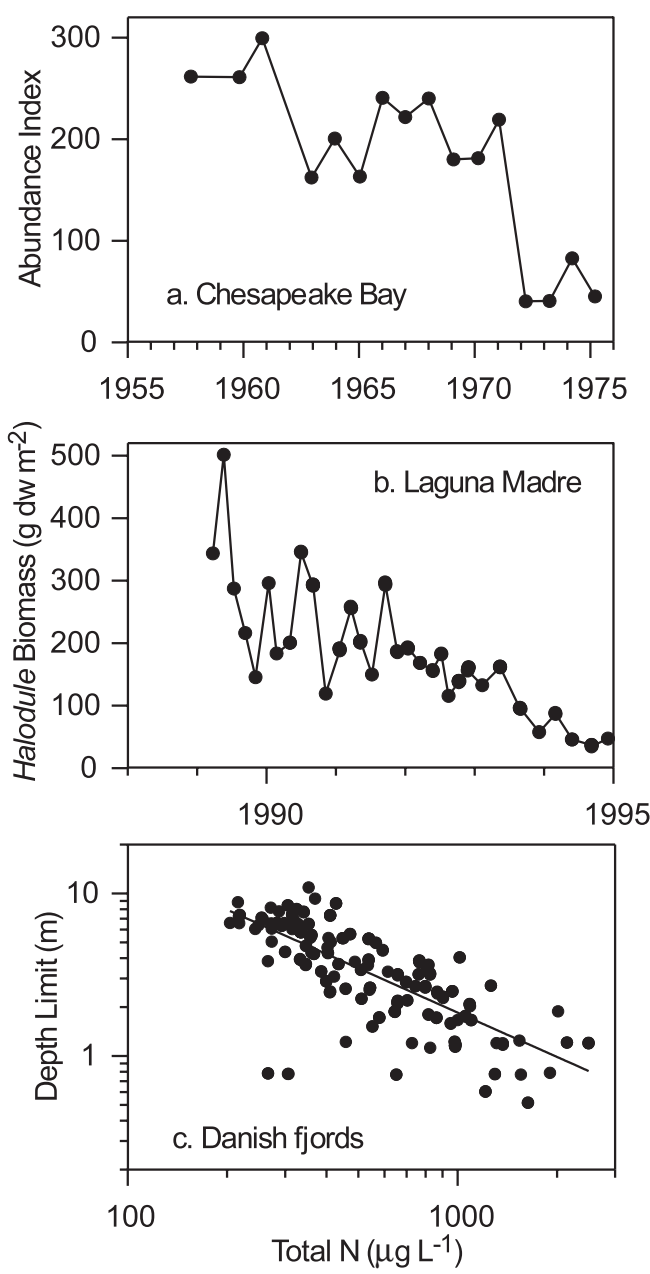

Fig. 13. Three indicators of declining abundance/distribution of submerged vascular plants in coastal ecosystems: (a) index of submerged vascular plant abundance in the Susquehanna Flats, Chesapeake Bay (redrawn from Bayley et al. 1978, Fig. 1); (b) changing root/rhizome biomass of the seagrass Halodule wrightii following the occurrence of a persistent brown-tide in Laguna Madre, USA (redrawn from Dunton 1996, Fig. 3); (c) empirical relationship between the habitat size (maximum depth of occurrence) of eelgrasses and the total $\mathrm{N}$ concentration of Danish fjords (estuaries) (redrawn from Christensen 1998, Fig. 5.7)

polychaetes, and reduced abundance of invertebrate prey for fishes and shorebirds (Raffaelli et al. 1998). Nutrient enrichment of tropical and subtropical waters has stimulated production of macroalgae, leading to the overgrowth and replacement of corals (Lapointe 1997).

We understand well that changes in the rates of production, deposition and oxygen-consuming metabolism of algal biomass are habitat disturbances that can propagate to cause change in populations of benthic invertebrates (Diaz \& Rosenberg 1995). Animal-community responses to change in organic enrichment are not linear or even monotonic, but rather follow a successional sequence beginning with increases in biomass and secondary production as food supply increases (Pearson \& Rosenberg 1978). Empirical evidence for this 'enrichment phase' (Gray 1992) includes the doubling of macrobenthos biomass in the Kattegat from 1973 to 1988, when phytoplankton biomass and primary production also doubled (Hagerman et al. 1996). Beukema's (1991) surveillance of macrozoobenthos in the Dutch Wadden Sea from 1970 to 1990, when phytoplankton (Fig. 7) and microphytobenthos biomass (Fig. 11) increased, also shows trends of biomass increase (Fig. 14a). Early responses also include changes in benthos species composition: Beukema's
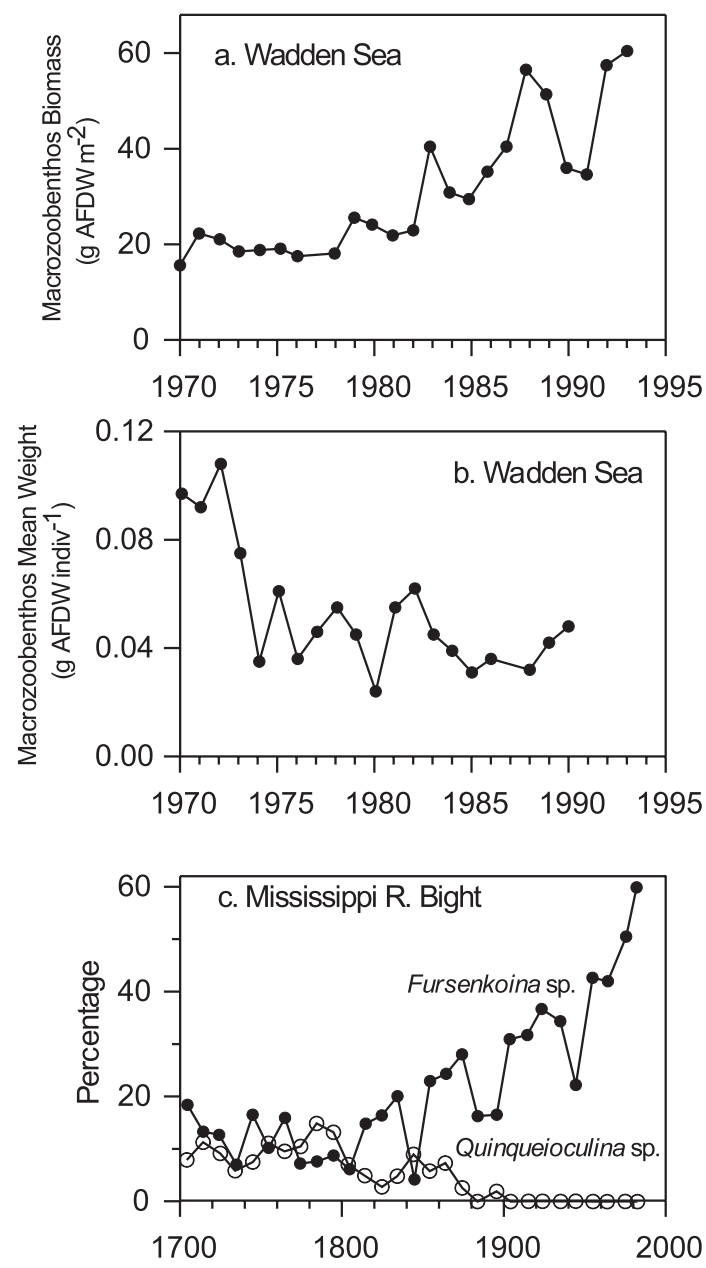

Fig. 14. Trends of change in the benthic invertebrate communities of 2 coastal regions: (a) change in macrozoobenthos biomass at Balgzand, western Dutch Wadden Sea (redrawn from de Jonge et al. 1996, Fig. 4; data from J. J. Beukema); (b) changes in the mean weight per individual of macrozoobenthos at Balgzand (redrawn from Beukema 1991, Fig. 1); (c) historical changes in the abundance of 2 species of foraminfera in the sediments of the Mississippi River Bight, northern Gulf of Mexico (redrawn from Rabalais et al. 1996, Fig. 11) 
record shows decreasing abundance of mollusks and crustaceans and increasing abundance of small-sized opportunist species (polychaetes), reflected as a trend of decreasing mean weight of individuals (Fig. 14b). Other trends of increasing benthic biomass (in Danish estuaries: Josefson \& Rasmussen 2000) and shifts in community composition (in the Oslofjord and Skagerrak: Rosenberg et al. 1987) have been linked to changes in nutrient loading.

Selection for fast-growing algal autotrophs by nutrient enrichment can lead to events of explosive population growth of microalgae or macroalgae, and the subsequent metabolism of that organic matter can deplete bottom waters of dissolved oxygen. In their comprehensive review, Diaz \& Rosenberg (1995) conclude: 'There is no other environmental variable of such ecological importance to coastal marine ecosystems that has changed so drastically in such a short period as dissolved oxygen. While hypoxic and anoxic environments have existed through geological time, their occurrence in shallow coastal and estuarine areas appears to be increasing, most likely accelerated by human activities. Ecological problems associated with the occurrence of low oxygen are increasing on a global scale.' Gray (1992) suggests a sequence of responses to developing hypoxia that includes: escape of sensitive demersal fishes (cod, whiting) when oxygen concentrations fall to 25 to $40 \%$ of saturation; escape of other benthic fishes (dabs, flounder) at $15 \%$ saturation; mortality of bivalves, echinoderms and crustaceans at $10 \%$ saturation; and extreme loss of benthic diversity at $<5 \%$ oxygen saturation when only the most resistant species of invertebrates (Capitella, Polydora) persist. Other studies have documented species shifts in the meiofaunal communities, some of which have been used as indicators of oxygen depletion. An example (Fig. 14c) shows historical changes (from cores) in the abundance of 2 species of foraminifera in sediments of the Mississippi River Bight. Progressive increase in the abundance of the hypoxia-tolerant Fursenkoina sp. since the 1950s is an indicator of increasing stress from oxygen-deficiency. Disappearance of the more sensitive Quinqueloculina sp. in the 1870s indicates that changes in oxygen concentration began in the last century (Rabalais et al. 1996).

Although it is difficult to establish a direct connection between enrichment-mediated shifts in invertebrate communities and upper trophic levels, Pihl (1994) has documented long-term changes in the diet of bottom-feeding fishes from the Kattegat and attributed these dietary shifts to changes in species composition of benthic macrofauna described above. He concludes that 'Repeated stress from hypoxia might favor smallsized prey species with a short life cycle, which would in turn favor small-sized fishes. Thus, altered food re- sources and the direct effects of hypoxia might result in shift in dominance among demersal fish species.' Our conceptual model now includes the hypothesis that nutrient enrichment can cause change in the selective forces that regulate biological diversity at all trophic levels within coastal food webs.

\section{Nutrient ratios and phytoplankton community composition}

The first conceptual model described linkages between simple bulk quantities such as total $\mathrm{N}$ loading and chlorophyll standing stock. As our understanding of the eutrophication problem has deepened, we have begun to appreciate the importance of other quantities such as the ratios of nutrients as forces that shape the evolution of plant and animal communities. A key topic of coastal research now centers around changes in the ratios of $\mathrm{N}, \mathrm{P}$, and $\mathrm{Si}$ and the impacts of changing nutrient ratios on the resource selection for particular groups of primary producers. Special emphasis is placed on the ratios of $\mathrm{Si}$ and $\mathrm{N}$ (or P) as the potentially limiting elements for diatoms, because human activities have selectively enhanced the loadings of $\mathrm{N}$ and $\mathrm{P}$, but not $\mathrm{Si}$, to coastal waters. Time series showing trends of increasing $\mathrm{N}$ concentration usually also show trends of decreasing Si:N ratios. Three examples (Fig. 15a to c) come from measurements in the Irish Sea, Mississippi River, and Bay of Brest. In each of these series, the Si:N ratio began at values $>1$ and then fell to ratios that are now consistently $\leq 1$. Diatoms require $\mathrm{Si}$ and $\mathrm{N}$ at a molar ratio of about 1 (Redfield et al. 1963, Dortch \& Whitledge 1992). As the Si:N ratio falls from $>1$ to $<1$, the chemical environment shifts from a state that allows diatoms to compete effectively with other algal classes, to a different state that gives selective advantage to the nondiatom taxa having small Si requirements (Officer \& Ryther 1980, Conley et al. 1993). A remarkable data set, of $\sim$ weekly sampling from 1962 to 1984 in the German Bight, shows: increases in nitrate concentration, decreases in silicate and declines in the $\mathrm{Si}: \mathrm{N}$ ratio to $<0.1$, with coincident increases in phytoplankton abundance and shifts in dominance from diatoms to flagellates/dinoflagellates (Radach et al. 1990).

Nutrient-resource competition theory (with roots in the limnological literature: Schelske \& Stoermer [1971]) is consistent with observations from coastal ecosystems showing distinct shifts in phytoplankton community composition from diatom dominance to progressively increasing importance of other taxa such as dinoflagellates and phytoflagellates (Fig. 16a). These species shifts have often been associated with changes in the intensity and/or duration of blooms of nondiatom species, some of which are toxic or harmful to other biota. 

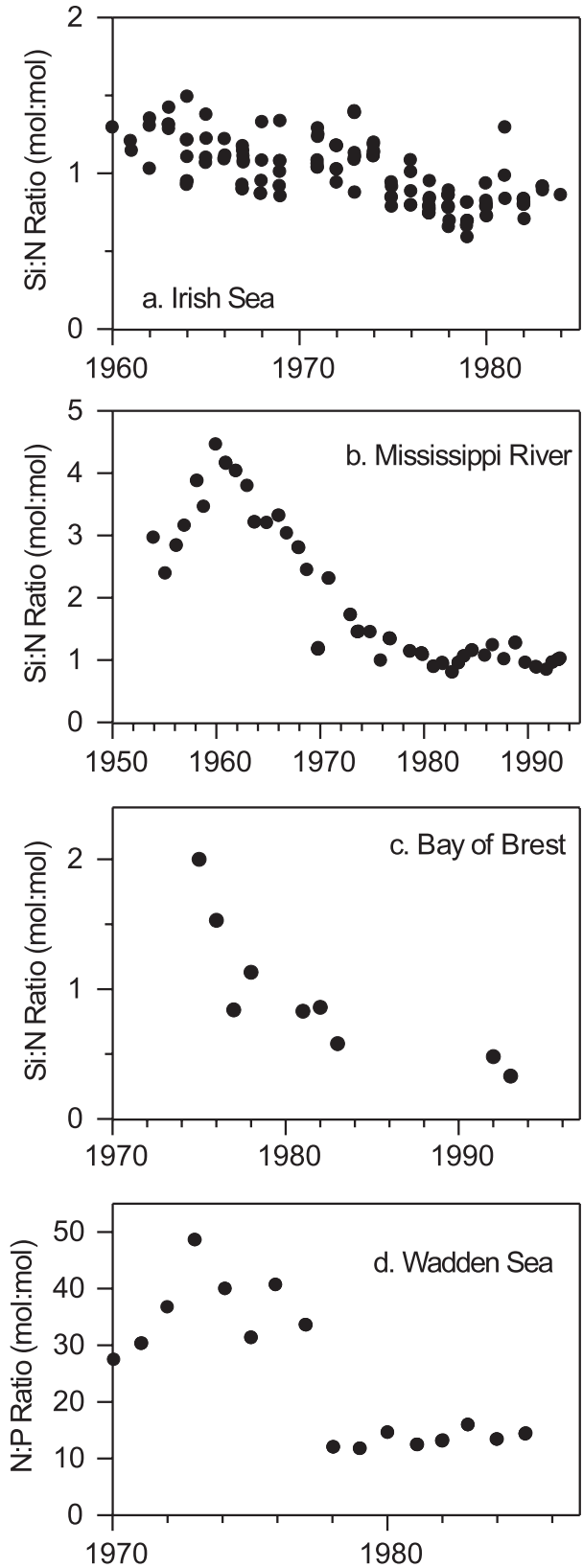

Fig. 15. Four examples of decadal-scale changes in the ratios of nutrient elements in coastal waters: (a) trend of decreasing Si:N ratio in the Irish Sea (redrawn from Allen et al. 1998, Fig. 3); (b) decreasing mean annual Si:N ratio in the lower Mississippi River (redrawn from Rabalais et al. 1996, Fig. 4); (c) decreasing Si:N ratio in the Bay of Brest, France, during summer months (Le Pape et al. 1996, Fig. 4); (d) decreasing total N:total P ratio in the western Dutch Wadden Sea during summer (redrawn from Riegman et al. 1993, Fig. 2)

One example is the record showing increased seasonal duration of nondiatom blooms (including the flagellate Phaeocystis sp.) in the Wadden Sea (Fig. 16b). Progressive increase in the intensity/duration of noxious Phaeo- cystis sp. blooms has coincided with decreases in the $\mathrm{N}$ :P ratio, from above the Redfield ratio of 16 to values below that critical ratio (Fig. 15d). Phaeocystis sp. is efficient at growing under N-limiting conditions (Riegman et al. 1992), so nutrient resources promote selective growth of this species when the N:P ratio falls below the Redfield ratio. A 21-yr series of measurements from the western Wadden Sea provides strong empirical evidence that human-induced changes in nutrient $(\mathrm{N}: \mathrm{P})$ ratios can cause changes in phytoplank-
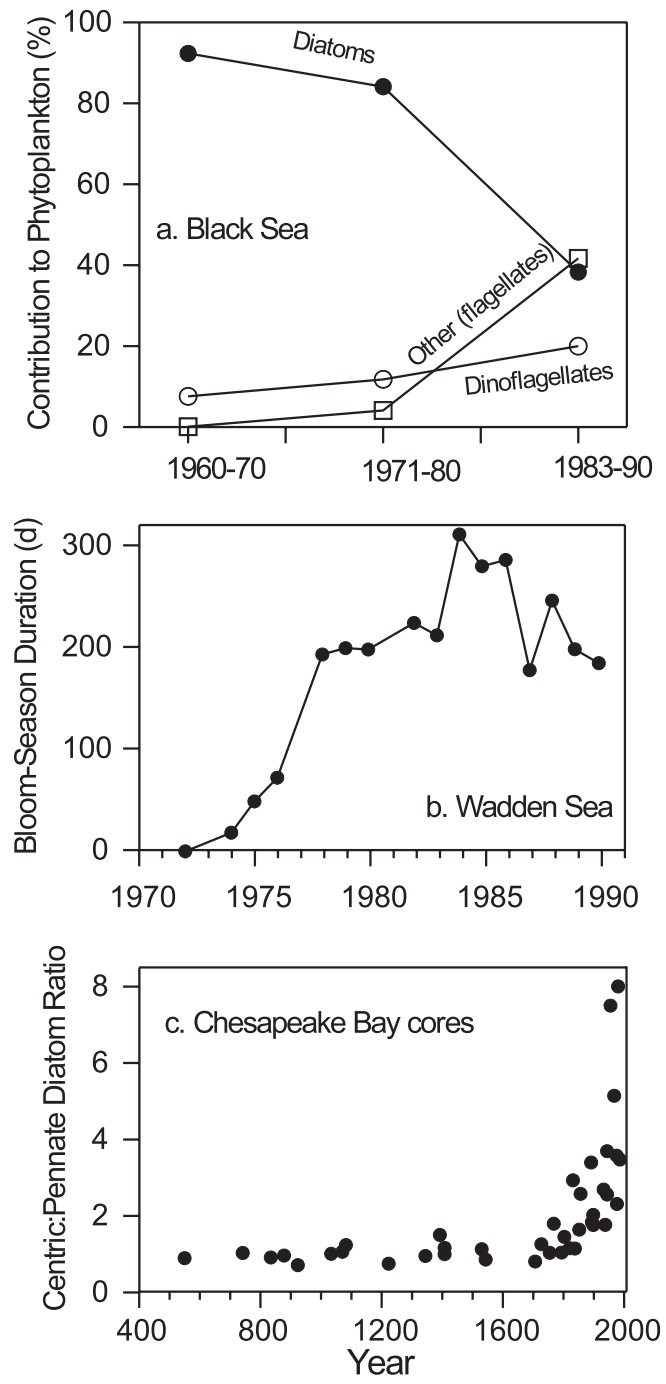

Fig. 16. Three different indicators of changing phytoplankton community composition in coastal waters: (a) decadal-scale decreases in the relative proportion (from cell counts) of diatoms and increases in the proportions of dinoflagellates and other taxa (phytoflagellates) in Romanian coastal waters of the Black Sea (Bodeanu 1993, Table 7); (b) duration of the season (d) of nondiatom blooms (cell density $>1000 \mathrm{ml}^{-1}$ ) at Marsdiep in the Dutch Wadden Sea (redrawn from Cadée 1992, Fig. 3b); (c) historical changes (from 4 cores) in the ratio of centric:pennate diatoms in the mesohaline Chesapeake Bay (redrawn from Cooper 1995, Fig. 8) 
ton species composition, and that these changes occur as discrete shifts from one community type to another (Philippart et al. 2000). The sedimentary record indicates that some shifts in phytoplankton community composition began as soon as estuarine watersheds were cleared for agriculture: there has been a strong shift in the relative proportions of centric and pennate diatoms in Chesapeake Bay (Fig. 16c), a trend indicative of nutrient enrichment (Cooper 1995).

In recent decades there has been an increase in the reported number of toxic algal blooms, including redtide events of dinoflagellate blooms in coastal waters. For some enriched coastal ecosystems, there is clear evidence of increased frequency of red tides; 3 examples (Fig. 17) come from monitoring programs in South Africa, Hong Kong, and the Seto Inland Sea, Japan. Changes in the intensity or frequency of algal blooms
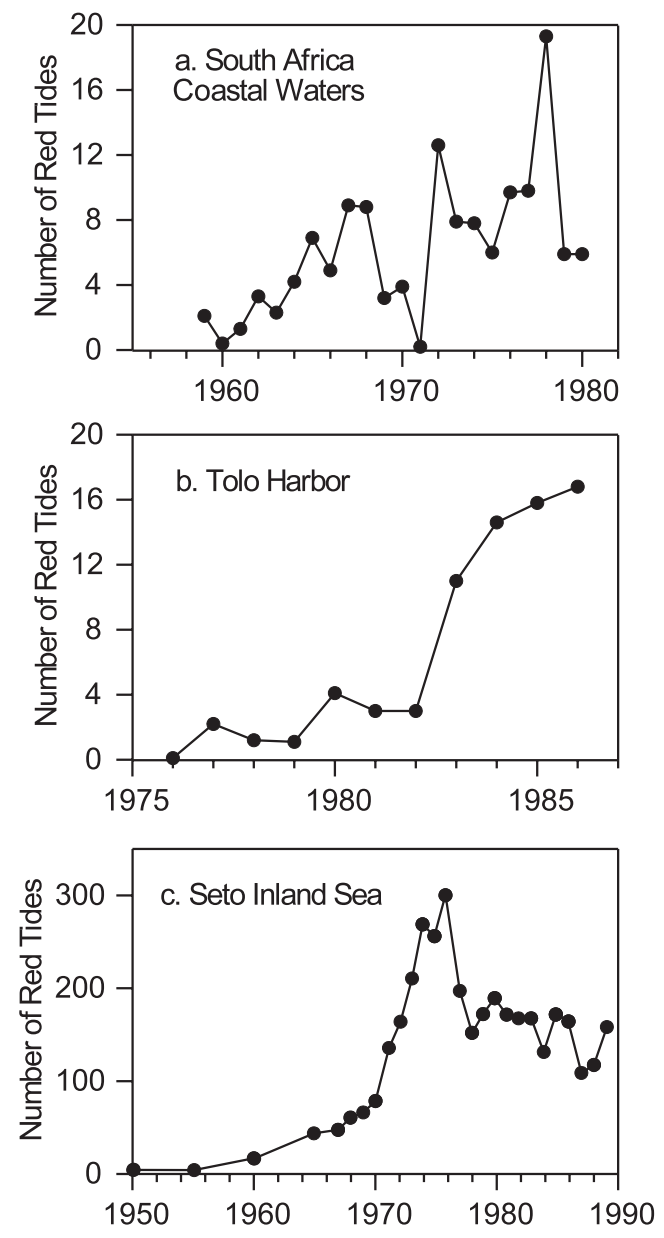

Fig. 17. Three examples of increasing occurrence of red tides in coastal ecosystems: (a) along the South African coast from $31.5^{\circ}$ to $35^{\circ} \mathrm{S}$ (redrawn from Smayda [1989], Fig. 2; original data from Horstman 1981); (b) Tolo Harbor, Hong Kong redrawn from Smayda 1989, Fig. 3; original data from Lam \& Ho 1989); (c) Seto Inland Sea, Japan (redrawn from Honjo 1993, Fig. 1) can be a threat to human health because some algal species produce toxins that are concentrated in shellfish harvested for human consumption, leading to neurological or gastrointestinal poisoning that can be fatal (see the review of Richardson 1997). Toxic events and red tides are global in scale. In recent years the Intergovernmental Oceanographic Commission of UNESCO (http://www.unesco.org/ioc/news/newslet/ htm) has reported toxic blooms of: Pseudonitzschia australis in California coastal waters; multiple species of dinoflagellates in Hong Kong and south China; brown tide species in Saldanha Bay and Langebaan Lagoon, South Africa; Gymnodinium mikimotoi in Wellington Harbor, New Zealand; Alexandrium tamarensis in Brazil, Uruguay, and Argentina; Prorocentrum minimum in Thermaikos Bay, Greece; red tides along the Salalah coast of Oman; Pyrodinium in Acapulco, Mexico; Alexandrium spp. in Alexandria Harbor, Egypt; Gymnodinium breve in south Florida; Gymnodinium catenata along the Atlantic coast of Morocco; Dinophysis in Loch Long, Scotland; Pseudonitzschia pungens in estuaries of Prince Edward Island, Canada; Alexandrium minuta in the Bay of Izmir, Turkey; Dinophysis along the northeast coast of Kamchatka, Russia; Pyrodinium bahamens in the Philippines; and Gymnodinium nakasagiense in southwestern India.

A causative connection between anthropogenic nutrient enrichment and increased frequency of harmful algal blooms has not been proven rigorously, although the hypothesis is now part of our conceptual model and supporting evidence is growing (Montresor \& Smetacek 2001). For example, Dale et al. (1999) examined dated strata from cores taken in the inner Oslofjord and observed a clear eutrophication signal as increased abundance of dinoflagellate cysts (indicating increased abundance of dinoflagellates) and large increases in the proportional abundance of 1 indicator species, Lingulodinium polyedrum. These signals grew during the period of increased nutrient loading from 1900 to 1980, and they diminished following steps to control waste nutrient loading around 1980. Rigorous proof is a challenge because harmful algal blooms are natural phenomena that have occurred throughout the Holocene (e.g. Fjellså \& Nordberg 1996) and before human disturbance of nutrient cycling (e.g. Bianchi et al. 2000). However, 'There exists a widespread belief that outbreaks of red tides are now becoming more frequent as a consequence of increasing eutrophication in coastal waters.' (Margalef 1998).

Blooms of toxin-producing or harmful algal species can impair the growth and reproduction of invertebrates and can be lethal to fish. For example, brown tides (Aureococcus anophagefferens) impaired reproduction of the copepod Acartia tonsa in Laguna Madre, 

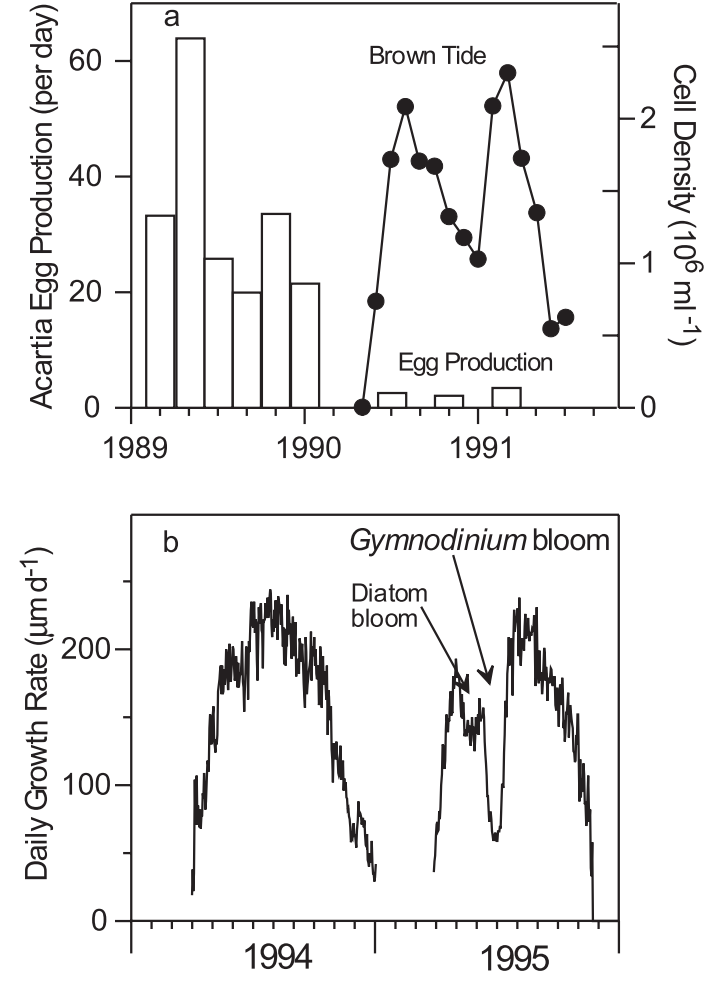

Fig. 18. Two examples of how toxic algal blooms can disrupt population processes of coastal marine invertebrates: (a) depression of egg production by the copepod Acartia tonsa during a brown-tide event in Laguna Madre, USA (redrawn from Buskey \& Stockwell 1993, Figs. 2 \& 5); (b) depression of scallop (Pecten maximus) growth in the Bay of Brest during a bloom of the dinoflagellate Gymnodinium cf. nagasakiense (data from Chauvaud et al. 2000, Fig. 9)

USA (Fig. 18a), and copepod egg production rates were strongly reduced during cyanobacteria blooms in the Baltic Sea (Sellner et al. 1996). Similarly, blooms of the toxin-producing dinoflagellate Gymnodinium cf. nagasakiense caused a marked depression of scallop (Pecten maximus) growth in the Bay of Brest (Fig. 18b). This series also showed smaller depressions of scallop growth following diatom blooms (Rhizosolenia delicatula, Chaetoceros sociale), presumably a result of mass sedimentation of diatom-derived organic matter onto the benthos surface, and its interference with scallop respiration (Chauvaud et al. 2000). Recent experimental evidence shows that some species of diatoms can impair invertebrates through another mechanismthe synthesis and excretion of aldehydes that block cell mitosis and arrest development of copepod and urchin eggs, leading to reproductive failure during diatom blooms (Poulet et al. 1994, Miralto et al. 1999). Therefore, changes in phytoplankton species composition can directly impact the population dynamics of metazoan consumers that utilize the phytoplankton as their primary nutritional source.

\section{Some responses can be reversed}

These direct and indirect responses to nutrient enrichment are expressed to varying degrees in different coastal ecosystems. For the most grossly polluted ecosystems, management actions have been taken to curtail anthropogenic nutrient loading, often in response to legislative mandates or enforcement of regulatory standards such as the US Federal Clean Water Act (Puckett 1995) or the Danish National Parliament's decision to reduce $\mathrm{N}$ and $\mathrm{P}$ loadings to Danish coastal waters by 50 and $80 \%$, respectively (Kronvang et al. 1993). For those coastal ecosystems in which management actions have been taken to remediate severe responses to anthropogenic enrichment, some recoveries have been impressive. Tampa Bay (USA) exhibited classic symptoms of over-fertilization in the 1970s: high chlorophyll biomass, high turbidity, noxious blooms of the cyanobacterium Schizothrix calicola, and disappearance of vascular plants. Remediation actions began with the implementation of efficient treatment of municipal wastes and reduction of $\mathrm{P}$ loading from phosphate-fertilizer producers in the watershed. By 1980 the annual wastewater loading of $\mathrm{N}$ was reduced 10-fold (Fig. 19a), and within a decade the mean chlorophyll biomass was reduced by more than half, the mean Secchi depth doubled, the intensity of Schizothrix blooms was greatly reduced, and the seagrass Halodule wrightii began to recolonize barren areas of the bay (Fig. 19b,c).

Natural experiments of climate anomalies, coupled with nutrient-reduction actions, illustrate the rapid rate at which some nutrient-enrichment responses can be reversed: $\mathrm{N}$ and $\mathrm{P}$ loadings from terrestrial runoff to Funen coastal waters in Denmark were reduced by 67 and $85 \%$, respectively, from the long-term mean loadings in 1995/96, the driest year of the 20th century. Changes that year included $50 \%$ reduction in the winter concentrations of DIN and DIP, unusually low chlorophyll concentrations and phytoplankton primary production in summer, increased water transparency (Secchi depth 1 to $2 \mathrm{~m}$ above the long-term mean), increased concentration of dissolved oxygen (by 1 to $3 \mathrm{mg} \mathrm{l}^{-1}$ ) in bottom waters, and recolonization of seedgerminated eelgrass in regions previously barren of vascular plants (Rask et al. 1999). Severe problems of anoxia have been eliminated with advanced waste treatment in the Forth Estuary and Thames Estuary, followed by recovery in the diversity of fishes previously decimated by anoxia (Fig. 20). Perhaps the most practical lesson we have learned in recent decades is that the primary responses to anthropogenic nutrient enrichment can be reversed with appropriate actions to reduce nutrient loadings. This lesson was also learned from actions taken to reduce phosphorus load- 

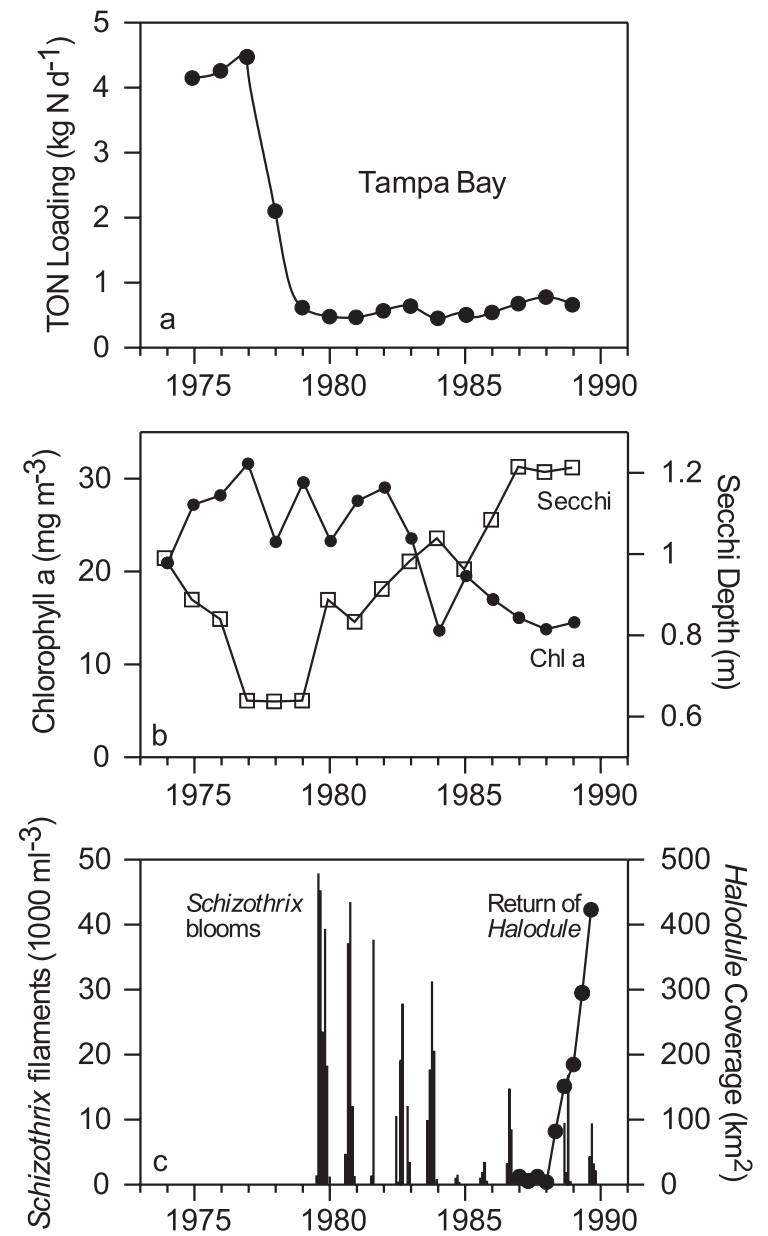

Fig. 19. An example of coastal-ecosystem rehabilitation following actions to reduce nutrient loadings, Tampa Bay, USA: (a) time series showing 10-fold reduction of $\mathrm{N}$ loading from municipal waste; (b) coincident trends of decreasing chlorophyll a concentration and increasing transparency (Secchi depth); (c) coincident decreases in the intensity of cyanobacterial (Schizothrix calcicola) blooms, and revegetation by the seagrass Halodule wrightii. Redrawn from Johansson \& Lewis (1992), Figs. 2, 8, 9, 10 \& 12

ings to lakes; remarkably fast recoveries occurred in Lake Norrviken, Sweden (Ahlgren [1977]; cited by Schindler [1981]) and in Lake Washington, USA (Edmondson 1991).

\section{Early responses to enrichment}

Finally, we are just beginning to recognize the importance of responses other than the primary responses of change in plant biomass, production, toxic-bloom frequency, or dissolved oxygen. These primary responses are probably the last, most visible stages in a succession of responses to chronic nutrient enrichment. Now we appreciate the impact of other, more subtle signs of disturbance that occur before the catastrophic symptoms. These early responses include changes in communities at the species level, indirect responses, changes in the rates of biogeochemical processes such as nutrient cycling (Nixon et al. 1986), and shifts in seasonal patterns or magnitudes of variability (Smetacek et al. 1991). An example in Fig. 21 shows a trend of change in the seasonal timing of phytoplankton biomass development in the Bay of Brest. Although this coastal system has not shown the primary response of elevated chlorophyll biomass in recent decades of elevated nutrient inputs, there has been a shift in the seasonal development of phytoplankton biomass such that the spring blooms have become smaller in amplitude but the summer biomass has become higher. This shift appears to be a response to 2 changes: (1) elevated inputs of $\mathrm{N}$ from the watershed, and (2) increased biomass and grazing by benthic suspension feeders, leading to more efficient retention of the biogenic silica produced during spring diatom blooms. The combination of exogenous inputs of $\mathrm{N}$ and increased benthic recycling of Si support higher summer biomass of diatoms (Chauvaud et al. 2000). Now we can begin to ask how these kinds of subtle seasonal-

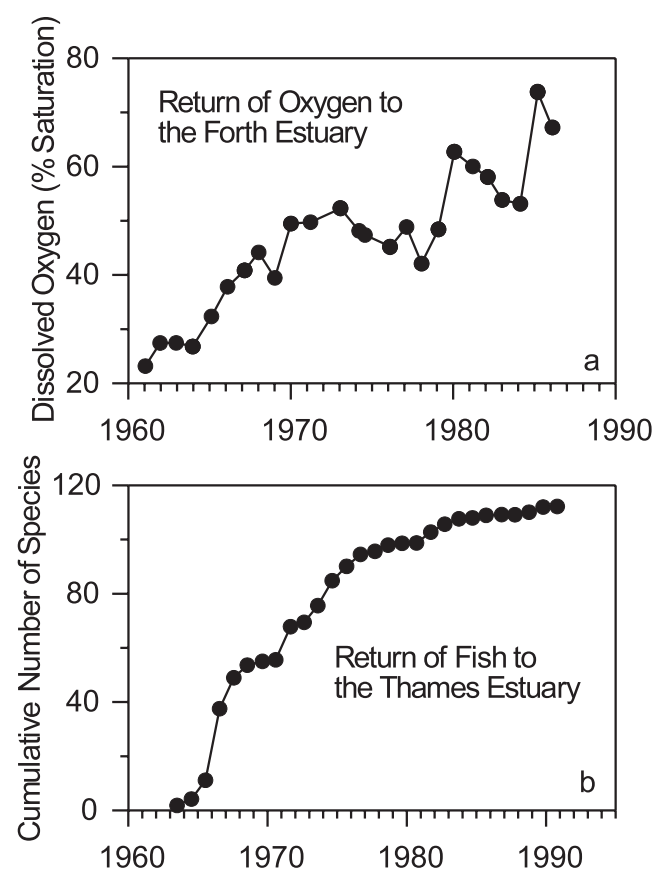

Fig. 20. Two examples of recovery following actions to restore water quality of estuaries impacted by nutrient and waste inputs: (a) trend of increasing DO concentration (summer months) in the Forth Estuary, Scotland, following improvements in wastewater treatment (redrawn from Griffiths 1987, Fig. 1); (b) trend of increasing diversity of fishes in the Thames Estuary following implementation of advanced wastewater treatment and increases in oxygen concentrations (redrawn from Attrill 1998, Fig. 1.3) 


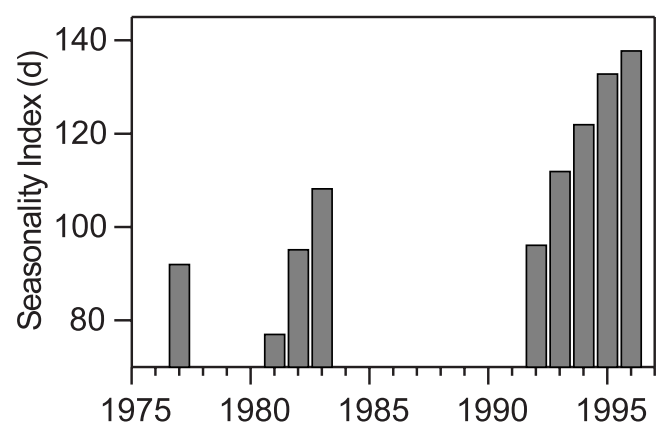

Fig. 21. Decadal-scale shifts in the seasonality of phytoplankton biomass development in the Bay of Brest. The index shows the number of days required to reach half the annual integrated chlorophyll biomass. High indices reflect seasonal delays caused by trends of increasing chlorophyll biomass during summer months (redrawn from Chauvaud et al. 2000, Fig. 6)

scale changes might cause change in other components of coastal ecosystems, and how these responses might be used as early-warning detection of systemic responses to nutrient enrichment.

\section{Today's conceptual model: Phase II}

This brief overview of progress made in recent decades shows that the contemporary view of coastal eutrophication has evolved well beyond the early conceptual model built around one set of responses to a signal of changing nutrient loading. A schematic of today's (Phase II) conceptual model (Fig. 22) shows 3 fundamental advances from the early model (Fig. 4). First, we have developed a clearer picture of the complex suite of potential responses to anthropogenic nutrient enrichment in the coastal zone, with explicit recognition of a set of direct and indirect responses. Central to our conceptual model is still the notion that nutrient enrichment can, in some coastal ecosystems, stimulate biomass accumulation of phytoplankton, followed by enhanced vertical fluxes of algal-derived organic matter to bottom waters and the sediments and development of hypoxia/anoxia. However other, equally important responses can include changes in the biomass of other algal communities including macroalgae and microphytobenthos, changes in nutrient ratios with subsequent shifts in phytoplankton community composi- tion and (apparent) increases in the frequency of toxic and harmful algal blooms. These primary, direct responses to enrichment can lead to another complex suite of secondary, indirect responses as changes in: water transparency; the distribution and abundance of vascular plants; biomass, community composition, and growth and reproduction rates of pelagic and benthic invertebrates; physical habitats for invertebrates and fishes including catastrophic disturbances that cause mass mortality of animals; inputs of organic carbon to sediments with another suite of changes in the redox state and biogeochemistry of the sediments; and subtle changes in the seasonal patterns of key ecosystem functions such as primary production. The contemporary view reflects a greater recognition of the complexity of the system-level responses that can follow changes in nutrient inputs to coastal ecosystems.

A second advance has come from our growing recognition that there are large differences among coastal ecosystems in the magnitude and character of their responses to enrichment. Our conceptual model now includes explicit recognition of system attributes that, together, act as a filter to modulate the response to the signal of change in nutrient loading (Fig. 22). Some estuarine-coastal systems appear to be very sensitive to change in nutrient inputs (e.g. Chesapeake Bay, Adriatic Sea, Baltic Sea, Black Sea, northern Gulf of Mexico). Others appear to have system attributes that dampen the direct responses to enrichment (e.g. San Francisco Bay, Bay of Brest, Ythan Estuary, Moresby Estuary, Australia [Eyre 1995], Westerschelde

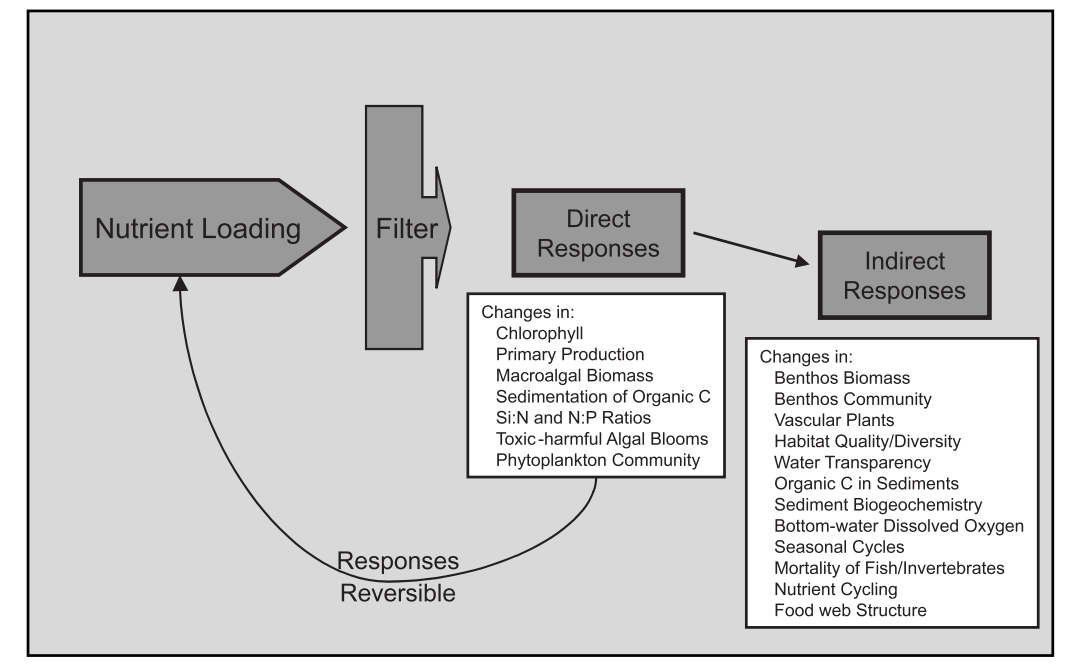

Fig. 22. Schematic representation of the contemporary (Phase II) conceptual model of coastal eutrophication. Advances in recent decades include explicit recognition of (1) a complex suite of both direct and indirect responses to change in nutrient inputs; (2) system attributes that act as a filter to modulate these responses; and (3) the possibility of ecosystem rehabilitation through appropriate management actions to reduce nutrient inputs to sensitive coastal ecosystems 
Estuary [Cloern 1999]). Because the strength of the filter is a system-specific attribute, it might be unrealistic to expect 1 general empirical model to describe response as a simple linear function of the nutrientloading signal (Gray 1992). Finally, we have learned from experience that appropriate actions to reduce anthropogenically-derived nutrient inputs can effectively reverse some of the direct and indirect responses (Fig. 22).

\section{A VIEW TO THE FUTURE: HOW CAN THIS SCIENCE ADVANCE?}

It is evident from the preceding review that, for some regions of the globe, we have made real progress toward answering the question of how anthropogenic nutrient enrichment causes change in coastal ecosystems. However this scientific discipline is still very young. The central problem presents an extraordinarily difficult scientific challenge (much harder than rocket science), and the contemporary conceptual model is still narrow and limited. Our view of the problem is narrow because it continues to focus on 1 signal of change in the coastal zone, as though nutrient enrichment operates as an independent stressor; it does not reflect a broad ecosystem-scale view that considers nutrient enrichment in the context of all the other stressors that cause change in coastal ecosystems. Our view is limited because it has been developed primarily from site-specific assessments, supplemented with only limited experimentation and simulation modeling. Our view is also limited because it comes primarily from intense effort in a few highly impacted regions of the developed world, mostly at temperate latitudes. This science has not yet evolved to the point where we have made a major investment in comparative analyses to synthesize the lessons from site-specific investigations into a comprehensive understanding of how nutrient enrichment promotes change in coastal waters, at the global scale.

This particular environmental problem merits sustained programs of integrated research and monitoring because the symptoms of damage to coastal regions of the world are so pervasive that they cannot be ignored. These symptoms include declines of living resources; 3 examples are shown in Fig. 23 to illustrate how some coastal populations of zooplankton, macrozoobenthos, and fishes have collapsed in recent decades. The disturbance of coastal ecosystems is a threat to the critical services they provide, valued globally at US $\$ 12.6$ trillion $\left(\$ 10^{12}\right)$ (Costanza et al. 1997). Changes in coastal water quality and living resources are the result of multiple stressors (Breitburg et al. 1999a), so a broader view of coastal eutrophication will consider how an-
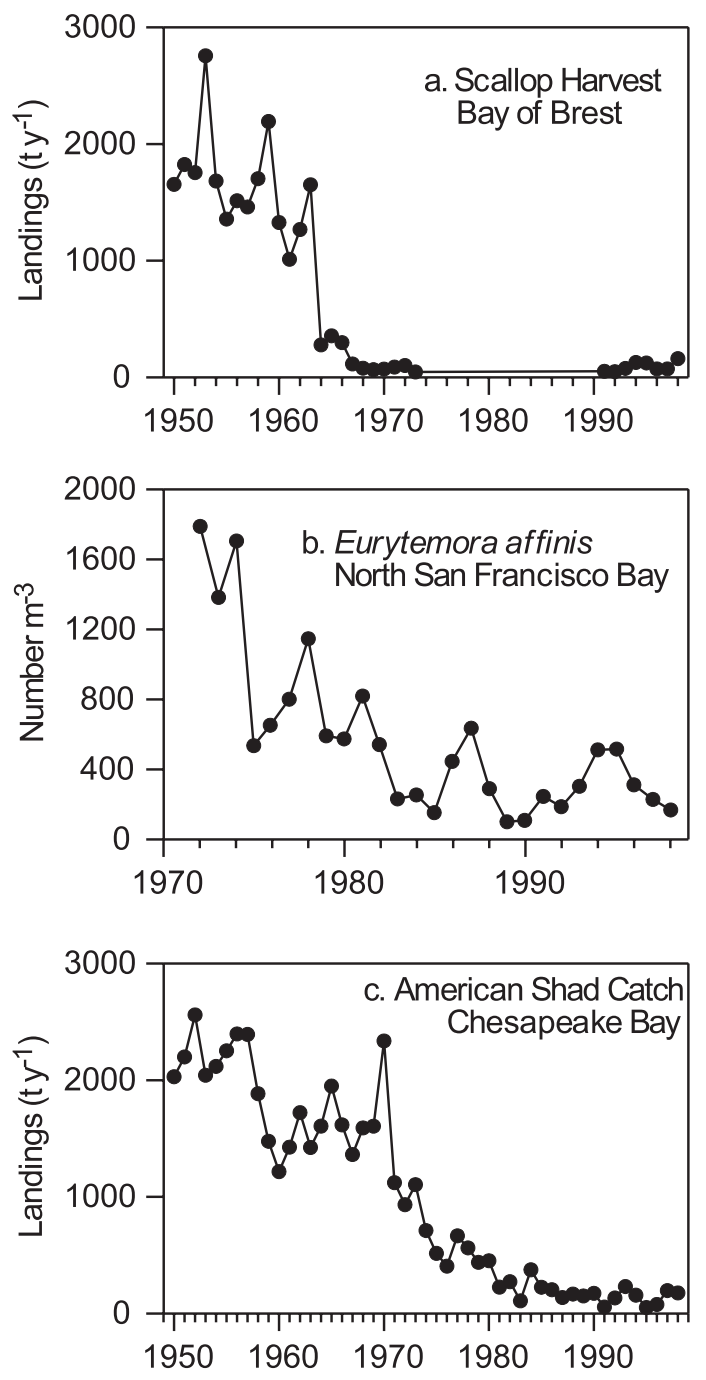

Fig. 23. Three examples of loss of living resources in coastal ecosystems: (a) benthic invertebrates, indexed as annual landings ( $\mathrm{t}$ ) of scallops in the Bay of Brest (data provided by L. Chauvaud; source: Comité Local des Pêches Maritimes de Brest); (b) pelagic invertebrates, indexed as the mean annual abundance of the brackish-water copepod Eurytemora affinis in northern San Francisco Bay (data from J. Orsi, California Department of Fish and Game: http://wwwiep.water.ca.gov/ neozoop/); and (c) finfish, indexed as the annual commercial catch of American Shad Alosa sapidissima in Chesapeake Bay (data from the US National Marine Fisheries Service: http://www.st.nmfs.gov/st1/commercial/index.html)

thropogenic nutrient enrichment interacts with other stressors such as translocation of species, habitat loss, fishing, inputs of toxic contaminants, manipulation of freshwater flows, aquaculture, and climate change. Deeper understanding of coastal eutrophication will require new research direction to explain how the responses to these multiple stressors are linked and how the responses interact. More effort at comparative analyses will lead to deeper understanding of how the 
responses to multiple stressors are modulated by the system-specific filter attributes. Finally, the next phase in the evolution of our conceptual model should produce a set of tools, reflecting a more mechanistic understanding of the problem, that can be used to guide strategies of coastal-ecosystem management, rehabilitation, or protection. The schematic in Fig. 24 presents 1 view of that next phase in the evolution of our conceptual model. Progress toward this broader perspective will require creative research approaches to answer 5 fundamental questions:

\section{(1) How does the filter work?}

Why are some coastal ecosystems highly sensitive to inputs of additional nutrients while others appear to be more resistant (at least to the primary responses)? Coastal research has brought us to the point where we have identified the component parts of the filter. These include inherent physical and biological attributes that operate in concert to set the sensitivity of individual ecosystems to nutrient enrichment. We know, for example, that tidal energy is an inherent attribute that strongly shapes the expression of eutrophication. Monbet (1992) revealed this with his comparison of 40 estuaries, showing that chlorophyll concentrations in microtidal estuaries are, on average, about 10 times higher per unit of DIN than in macrotidal estuaries (Fig. 25). Of course the presence of tides is 1 distinction between lakes and coastal ecosystems, and we are beginning to understand how the tidal component of the filter works. One mechanism is the production of turbulence by tidal stresses at the bed. As tidal currents accelerate, the production of turbulent kinetic energy grows and can become the largest source of mixing energy in shallow coastal waters. Coastal ecosystems also differ from lakes by the presence of salinity gradients that can create vertical density stratification. The balance between the opposing buoyancy force from salinity stratification and tidal stirring is a key physical attribute that shapes the phytoplankton response to nutrient enrichment (Lucas et al. 1998). The difference in the tidal amplitude of Chesapeake Bay and San Francisco Bay is 1 mechanism for producing their different responses to the same signal of high nutrient loading (Fig. 6). This mechanism explains why the primary responses to nutrient enrichment are, in general, most extreme in regions with small tidal energy (Baltic, northern Gulf of Mexico, Adriatic, Black Sea).

A second physical attribute is the set of horizontal transport processes that determines the residence time of water, nutrients, and plankton within coastal basins. Numerical models illustrate a second principle: algal
(2) Multiple Stressors

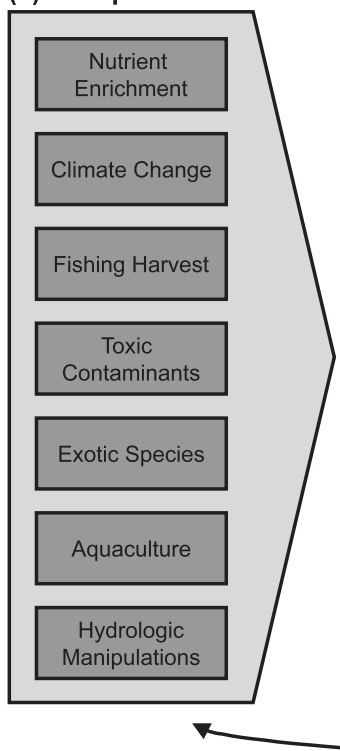

(3) Coastal Ecosystem Responses

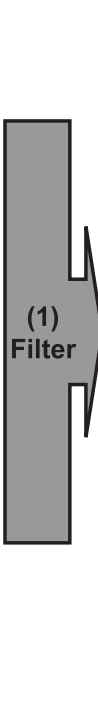

(4) Impacts on the Earth System

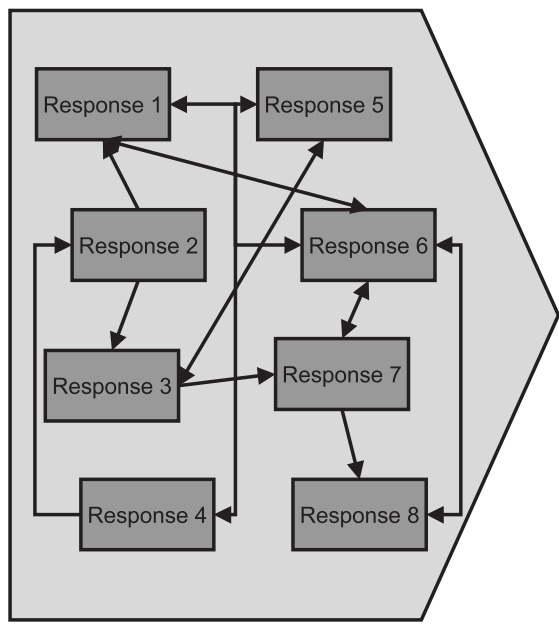

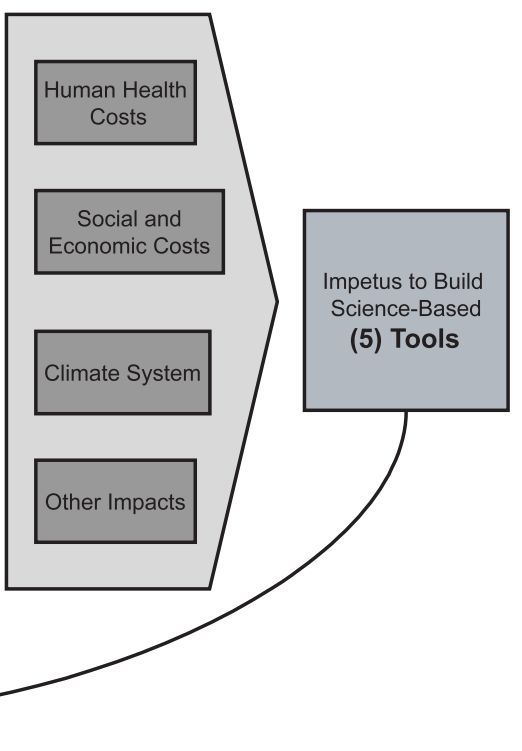

Fig. 24. One view of the next (Phase III) conceptual model of coastal eutrophication, organized around 5 basic questions concerning: (1) the system attributes that act as a filter to modulate the responses to nutrient enrichment; (2) nutrient enrichment as 1 of many interacting stressors; (3) the complex linkages between responses to multiple stressors; (4) impacts of change in coastal ecosystems on the Earth system, including aspects that influence sustainability of the human population; and (5) the application of a deeper and broader scientific understanding of coastal eutrophication to produce a set of tools for building rational management strategies and action plans for ecosystem rehabilitation/restoration 


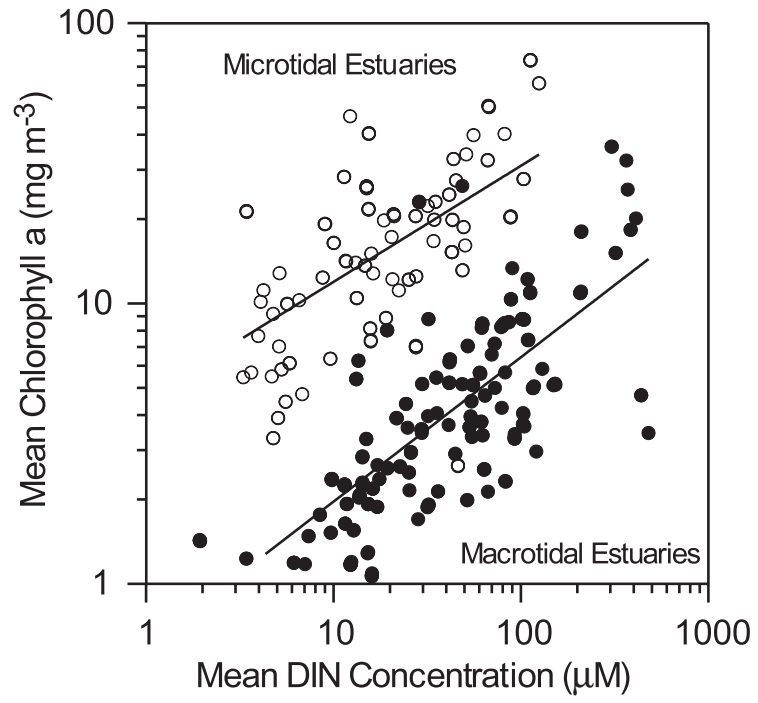

Fig. 25. Example of a response (mean annual chlorophyll a concentration) to the signal of mean DIN concentration, after estuaries are separated into macrotidal (mean tidal range $>2 \mathrm{~m}$ ) and microtidal (mean tidal range $<2 \mathrm{~m}$ ) bins. Redrawn from Monbet (1992), Fig .2

bloom dynamics are controlled by the balance between the rates of phytoplankton population growth and horizontal transport (Lucas et al. 1999a,b). Horizontal transports are controlled by physical attributes (tides, wind, bathymetry, basin geography, river flow), all of which contribute to the filter function. Coastal ecosystems with slow transports and long residence times tend to retain exogenous nutrients (Fig. 26) and therefore have less efficient filters than coastal ecosystems with short residence time.

A third physical attribute is the set of optical properties that controls the light exposure to submerged plants, including the phytoplankton. The algal com-

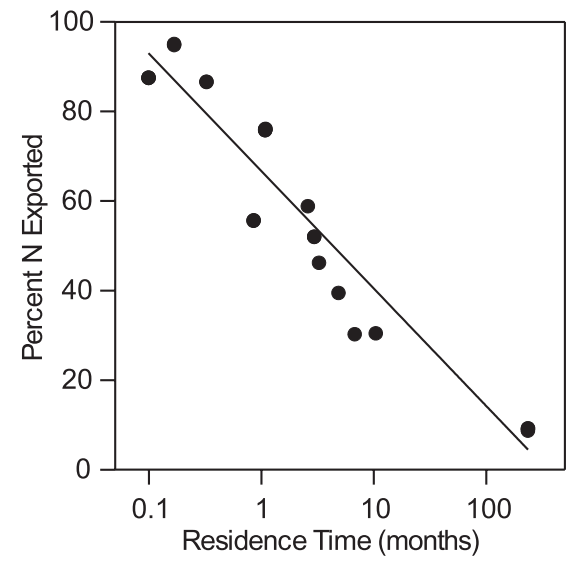

Fig. 26. Percentage of $\mathrm{N}$ input that is exported from 12 different estuaries, shown as a function of water residence time. Redrawn from Nixon et al. (1996), Fig. 1 munities require both light energy and nutrients to produce new biomass, and for many coastal waters the inherent optical properties are such that photons are more scarce, relative to plant requirements, than are atoms of $\mathrm{N}$ or P (Cloern 1999). For some set of estuaries, annual primary production is more strongly correlated with measures of the light resource (Fig. 27) than with measures of the nutrient resource. This optical component of the filter also helps to explain why Chesapeake Bay is more responsive to nutrient additions than San Francisco Bay, which has higher suspended sediment concentrations and higher turbidity.

Finally, we have a strong sense now of the importance of suspension feeders as a biological component of the filter. A third distinction between (most) lakes and coastal waters is the biological component of benthic-pelagic coupling associated with the comparatively high biomass of benthic suspension feeders in marine systems. The rate of particle filtration by the community of benthic suspension feeders can be high enough to balance the rate of phytoplankton primary production (Cloern 1982), so this top-down process can be a key biological component of the filter. The best predictor of chlorophyll a concentration in Danish estuaries is the biomass of mussels (Fig. 28a), rather than any quantity related to nutrient fluxes or concentrations. This data set shows a significant inverse relationship between chlorophyll biomass and mussel biomass, implying strong grazing control of the responses to enrichment, even in nutrient-rich estuaries. Meeuwig's (1999) analysis of chlorophyll biomass in 15 Canadian estuaries produced identical results. This biological regulator is dynamic and adaptive: simulation experiments with a carbon-flow model of the Oosterschelde estuary suggest that a doubling of nutrient

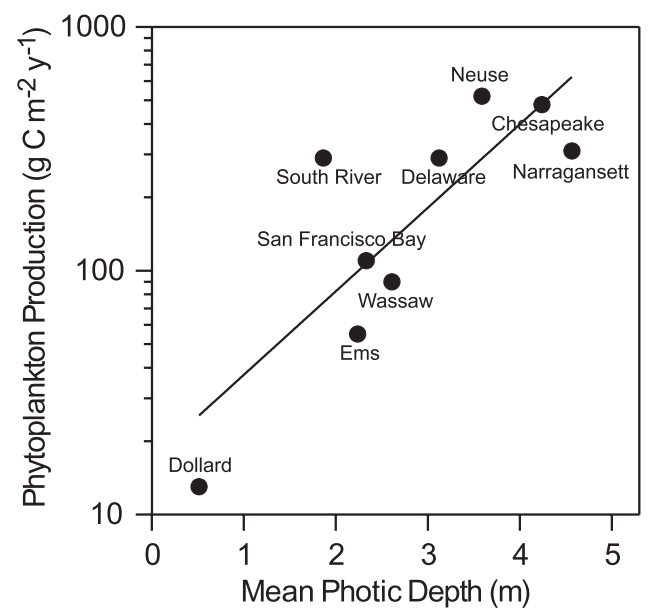

Fig. 27. Annual phytoplankton primary production in 9 estuaries versus mean photic depth. From Peterson et al. (1987), Table 1 

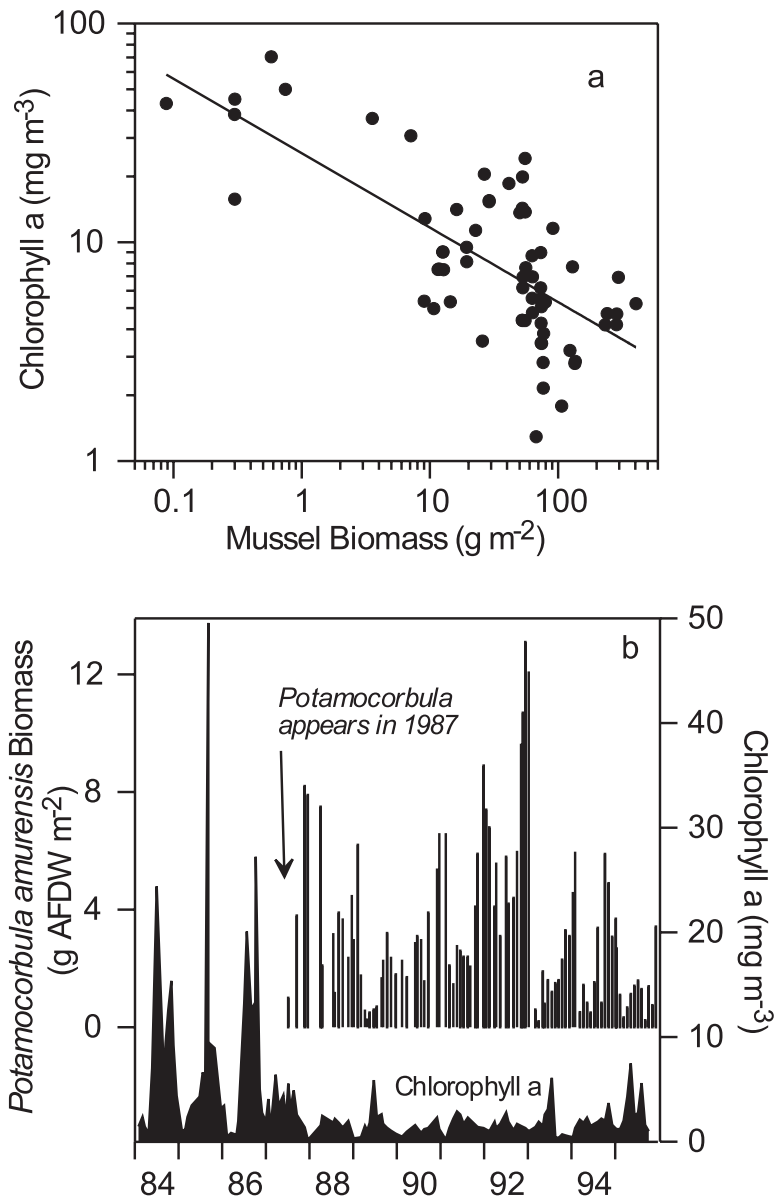

Fig. 28. Two indicators of top-down (bivalve grazing) control of phytoplankton biomass in coastal ecosystems: (a) mean annual chlorophyll concentration in Danish fjords (estuaries) vs mean biomass of mussels (fitted line shows the function $\log y=1.39-0.34 \log x ; \mathrm{r}=-0.71)$, redrawn from Kaas et al. (1996), Fig. 5.5; (b) time series of chlorophyll a concentration and mean abundance of the nonindigenous clam Potamocorbula amurensis before and after its introduction to northern San Francisco Bay (data from the US Geological Survey [http://sfbay.wr.usgs.gov/access/wqdata/query/] and the California Department of Fish and Game [http://wwwiep.water. ca.gov/dbms/])

loading will produce only small increases in phytoplankton biomass because of adaptive increases in phytoplankton consumption by the suspension feeders (Herman \& Scholten 1990). We have learned also, from sustained observational programs, that the balance between phytoplankton production and loss to benthic consumers can be disrupted by the colonization of coastal ecosystems by nonindigenous suspension feeders. This occurred in northern San Francisco Bay when the Asian clam Potamocorbula amurensis became widely established in 1987; since then, chlorophyll biomass has been persistently low and primary production has been reduced 5-fold (Alpine \& Cloern 1992;
Fig. 28b). This biological process contributes further to the differential responses of Chesapeake Bay and San Francisco Bay.

Although we now have a clear sense of the system attributes that comprise the filter, we do not understand how these components work together. This understanding is central to the next (Phase III) conceptual model of the coastal eutrophication problem (Fig. 24). It will develop as we invest more research in comparative analyses to reveal the mechanisms of resistance to nutrient enrichment. Perhaps the most rapid progress will come when results from observational programs are analyzed with numerical tools that integrate all the component parts of the filter (e.g. Lucas et al. 1999a,b).

\section{(2) How does nutrient enrichment interact with other stressors? (3) How are responses to multiple stressors linked?}

Most publications on coastal eutrophication present results from the perspective that nutrient enrichment is an isolated signal (Fig. 22). However, by the end of the 20th century environmental scientists recognized the need to analyze ecosystem changes as responses to multiple stressors, and to consider the myriad potential interactions among those stressors (e.g. Breitburg et al. 1999a). We know that coastal ecosystems are changing in response to all the stressors shown in Fig. 24. We do not, however, have a deep understanding of how these different signals operate together.

One strong interaction is with the climate system because it is such a powerful source of environmental variability that influences all the signals shown in Fig. 24, as well as all the components of the filter. Climatically driven pulse inputs of nutrients, either from terrestrial runoff (Hama \& Handa 1994) or atmospheric deposition (Paerl et al. 1990), can trigger responses such as algal blooms and anoxia. Conversely, these expressions of eutrophication are weakest during climate anomalies of low precipitation and nutrient runoff (Rask et al. 1999). Climatic events change all the physical components of the filter: as residence time is prolonged during low-flow conditions, algal blooms frequently develop within estuaries (Relexans et al. 1988); storm-related events of high river flow can establish strong vertical salinity gradients and development of hypoxia/anoxia in bottom waters (Paerl et al. 1998). In weakly tidal systems, where wind stress is the important mechanism of vertical mixing, weather anomalies can induce responses: a $7 \mathrm{wk}$ period of calm winds and warm temperature established persistent thermal stratification, bottom-water anoxia, and mortality of half the mussel population in the Danish Limfjord in 1997 (Møhlenberg 1999). Climate-driven 
changes in coastal hydrology and circulation can determine whether potential responses to nutrient enrichment are realized: a series of large-scale red tides and regional fish kills occurred in Hong Kong coastal waters during the 1997-98 El Niño, presumably because of changes in the south China Coastal Current that prevented offshore transport of Gyrodinium aureolum blooms sustained by land-derived nutrients (Yin et al. 1999). Exceptional brown tides developed in many estuaries of the northeastern US in 1985, partly because of prolonged water residence during this period of anomalous regional wind stress and damped Ekman pumping as a mechanism of estuary-ocean exchange (Vieira \& Chant 1993). Many catastrophic responses to nutrient enrichment occur during climatic anomalies (e.g. Maestrini \& Granéli 1991, Zingone et al. 1995), so the climate-eutrophication linkage is established. To what extent will humandriven changes in the global climate system alter the ways in which coastal ecosystems assimilate exogenous nutrients?

A second, virtually unexplored interaction is with the stressor of human manipulation of coastal hydrology. The unique character of coastal ecosystems derives from their position at the land-sea interface where they are influenced by variability at both the seaward and watershed boundaries. River flow is a prominent source of natural variability that has now become highly manipulated by man: nearly $80 \%$ of the fresh water discharged by large rivers in the northern temperate zone is 'strongly or moderately affected by fragmentation of the river channels by dams and by water regulation resulting from reservoir operation, interbasin diversion, and irrigation' (Dynesius \& Nilsson 1994). Human control of the seasonal timing and quantity of freshwater discharge to the coastal zone is a disturbance that changes river chemistry, nutrient fluxes to estuaries, and the capacity of estuaries to assimilate nutrients. The impoundment of large rivers has created an artificial mechanism (retention of biogenic silica produced by diatoms in reservoirs) that reduces $\mathrm{Si}$ fluxes to the coastal zone (Humborg et al. 2000). Dissolved silicate loads from the Danube River were reduced by two-thirds following dam construction after 1970 (Humborg et al. 1997). The resulting decrease in the Si:N ratio of Danube outflow appears to be a primary agent of change in the phytoplankton community in the coastal Black Sea (Fig. 16a). In a similar way, impoundment and rerouting of flows through Lake Ijssel Netherlands caused a doubling of P discharge and contributed to the decreased N:P ratio (Fig. 15d) and increased abundance of Phaeocystis sp. in the Dutch Wadden Sea (Riegman et al. 1992). Dam operations can cause catastrophic responses comparable to those attributed to nutrient enrichment: a large-scale release of water from the Arzal Dam induced strong salinity stratification followed by bottom-water anoxia, fish kills, and complete mortality of benthic megafauna over $400 \mathrm{~km}^{2}$ in the Vilaine Estuary, France, in 1982 (Rossignol-Strick 1985). Large-scale coastal engineering projects, such as damming of the Rhine-Meuse Estuary, filling/diking of virtually all tidal marshes around San Francisco Bay (Nichols et al. 1986), port construction in Venice Lagoon, flow diversions and resulting hypersalinity of the Ciénaga Grande de Santa Marta, Colombia, and construction of the Oosterschelde storm-surge barrier have transformed these coastal ecosystems from their pristine states to altered states with increased algal biomass (Sfriso et al. 1993), shifts in phytoplankton species (Bakker et al. 1994), or massive losses of mangroves (Perdomo et al. 1998) and nursery habitats for marine fishes (Smit et al. 1997). We do not yet explicitly consider the eutrophication problem as one that operates in highly engineered physical systems, but this perspective will develop as the science matures.

An equally powerful mode of human disturbance is the global translocation of organisms and inoculation of coastal ecosystems with nonindigenous species, a disturbance that 'renders bays, estuaries, and inland waters among the most threatened ecosystems in the world' (Carlton \& Geller 1993). As an extreme example, San Francisco Bay has been colonized by 212 exotic species of plants and animals, and the invasion continues at the current rate of one new species every 24 wk (Cohen \& Carlton 1995). These inoculations sometimes cause a profound ecological disturbance, and this disturbance interacts with nutrient enrichment in ways that we have not yet imagined. The most direct interaction comes from the translocation of harmful algal species to nutrient-enriched coastal waters: unprecedented occurrences of paralytic shellfish poisoning in Australian coastal waters during the 1980s may have resulted from the transport and delivery of 3 nonindigenous species of toxic dinoflagellates via ship ballast (Hallegraeff 1993). More complex interactions occur when nutrient enrichment and species introductions work in concert, but through different mechanisms, to disrupt coastal populations. Extreme examples are the recent biological changes in the Black Sea, which have included $>10$-fold declines of copepods and other mesozooplankton and collapse of the Turkish anchovy fishery. Mee (1992) and Kideys (1994) suggest that these changes are responses to disturbance by $\mathrm{N}$ and $\mathrm{P}$ enrichment (which has changed the quality of the phytoplankton food resource for zooplankton) and the greatly enhanced predation mortality of zooplankton and larval fishes caused by the explosive population growth of the nonindigenous ctenophore Mnemiopsis leidyi. Analogous interactions have con- 
tributed to stock declines of the scallop Pecten maximus in the Bay of Brest. This valuable species is stressed by toxic dinoflagellate blooms that impair growth of adults (Fig. 18b) and survival of juveniles, plus growing competition for space from the introduced mollusk Crepidula fornicata (Chauvaud 1998). The indigenous Pecten maximus is more sensitive to the toxicity of Gymnodinium blooms than the introduced mollusk, so an indirect response to nutrient enrichment can be habitat change that facilitates ecosystem colonization by nonindigenous species.

We have not yet begun to seriously explore the interactions between toxic contaminants and nutrients, although we know that human activities produce and transport industrial and agricultural pollutants to coastal marine systems (e.g. Fowler 1990). Heavy metals such as silver (Sanders \& Cibik 1988) and copper (Kuwabara et al. 1989), chlorinated hydrocarbons (DDT and PCB's; Mosser et al. 1972), and herbicides such as atrazine and diuron (Edmunds et al. unpubl.) all selectively inhibit some classes or species of algae, and therefore promote population growth of the less-sensitive taxa. But how does the species-selective response to $\mathrm{N}$ and $\mathrm{P}$ enrichment operate in concert with the species-selective responses to the complex mosaic of toxic compounds? Could some harmful algal blooms, which are often the result of explosive growth of 1 or a few species, partly be the result of the combined selective forces from enrichment with nutrients and toxic contaminants? Algal assimilation is a biological process that can regulate the bioavailability and trophic transfer of reactive toxic elements (Reinfelder \& Fisher 1991, Luoma et al. 1992) and PCB's (Mailhot 1987, Stange \& Swackhamer 1994). Laboratory experiments and measurements in Swedish coastal waters suggest that nutrient stimulation of phytoplankton production leads to enhanced accumulation of PCB's in the tissues of infaunal brittle stars, the first step in the transfer of these contaminants to higher trophic levels (Gunnarsson \& Sköld 1999). Algal assimilation of metals such as cadmium, nickel and zinc also acts as a biological trapping mechanism to retain these elements within coastal basins (Luoma et al. 1998). To what extent is the efficiency of trophic transfer and the biological trapping of toxic substances enhanced by nutrient stimulation of algal production? The speciation and toxicity of some contaminants, such as arsenic and copper (Sanders \& Riedel 1993), are also transformed by algal metabolism or excretory products. Does nutrient-enhanced algal production cause change in the overall toxicity of contaminants discharged into coastal waters? Mesocosm experiments suggest that there are strong interactive responses to additions of nutrients and trace elements, including interactions through which nutrient enrichment amplifies the biological responses to toxic metals such as impairment of the growth and production of marine biota (Breitburg et al. 1999b).

The complex interactions shown in Fig. 24 are not static, but rather are dynamic responses to changing human activity. An anthropogenic stressor of growing importance is aquaculture, the fastest-growing agricultural activity in the US and one of rapid global expansion during the 1990s (Fig. 29). Intense cultivation of fish and shellfish in coastal waters can be a source of environmental disturbance associated with unnaturally high concentrations and deposition of organic matter that alter sedimentary processes and oxygen concentrations. Shellfish culture has a strong influence on the nitrogen cycle by enhancing the deposition of organic matter to the sediments, reducing oxygen availability and promoting dissimilatory processes of $\mathrm{N}$ cycling. In the Thau Lagoon, France, used for intense oyster culture, these changes reduce the loss of nitrogen to denitrification and therefore retain $\mathrm{N}$ available to sustain primary production (Gilbert et al. 1997). Similar responses were measured in Upper South Cove, Nova Scotia, where sediments beneath cultured mussels release large quantities of ammonium and act as a net source of $\mathrm{N}$, compared to reference sites which act as an N sink (Hatcher et al. 1994). Intense shellfish farming therefore increases the retention of nitrogen within coastal systems.
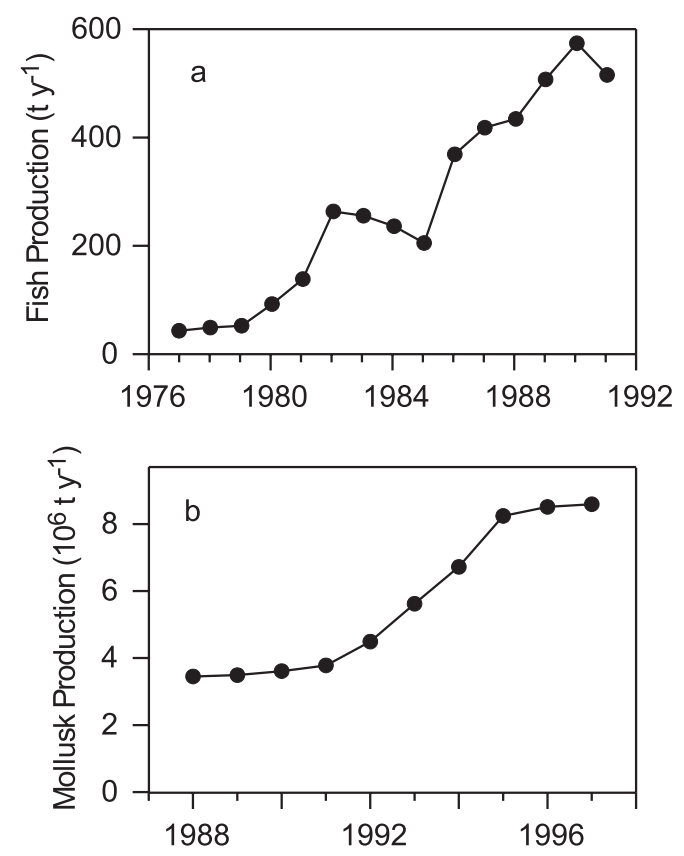

Fig. 29. Two indicators of the rapid growth of aquaculture in coastal waters: (a) annual production of farmed fish in the Åland Sea (redrawn from Bonsdorff et al. 1997b, Fig. 6); and (b) annual global production of mollusks from 1988 to 1997 (data from the FAO http://www.foa.org/fi/statist/summtab/ default.asp) 
Finfish culture is growing at an equally rapid rate and this activity leads to similar responses of organic enrichment and enhanced microbial activity of sediments, and also promotes development of toxic algal blooms (Kaartvedt et al. 1991). Cultured shellfish consume natural phytoplankton but cultured finfish are supplied feed, so this activity also acts as a new source of nutrients. In the Åland archipelago, where harvest of farmed rainbow trout (Oncorhyncus mykiss) increased >10-fold from 1977 to 1991 (Fig. 29a), fish farms now contribute more P (by $15 \times$ ) and $N$ (by $3.6 \times$ ) than treated wastewater (Bonsdorff et al. 1997b). This region of the northern Baltic exhibits multiple symptoms of change in response to nutrient enrichment, even during an era of improved wastewater treatment. Other human activities that act as nutrient sources can therefore offset the benefits of controlling only 1 source of $\mathrm{N}$ and $\mathrm{P}$.

Fishing harvest contributes directly to stock declines (Fig. 23) and it influences the system-level responses to nutrient enrichment: the oyster population of Chesapeake Bay has declined more than 50 -fold this century, and this loss is attributed primarily to stock overfishing and to mechanical disturbance of habitat (Rothschild et al. 1994). Loss of native suspension-feeding bivalves of this magnitude has decreased the estuary's topdown grazing control of phytoplankton biomass (Newell 1988), illustrating that human activities unrelated to nutrient enrichment can alter the system properties that modulate the eutrophication response.

The next conceptual model will emerge as we leave behind the notion of nutrient enrichment as an isolated stressor and replace it with the more challenging notion that coastal ecosystems are subjected to multiple interactive stressors (Fig. 24), and that responses to these stressors are intimately interconnected. A fundamental challenge for coastal scientists is to find creative approaches for revealing the complex interactions of coastal ecosystem change depicted in Fig. 24.

\section{(4) How does coastal eutrophication impact the Earth system as habitat for humanity?}

A fourth challenge is to define more clearly the responses to nutrient enrichment that change other attributes of the Earth system, beyond the biogeochemistry and ecology of its coastal waters. What are the social and economic costs of human disturbance to the coastal zone, especially since estuaries provide more valuable ecosystem services per unit surface area than any other biome on the planet (Costanza et al. 1997)? We know from specific case studies the economic and social costs of changes such as the 1987-1989 collapse of the Turkish anchovy fishery harvest from the Black
Sea, which supplied $80 \%$ of that nation's demand for fish and represents an important national loss of income and protein (Mee 1992). Similar declines in fish stocks and diversity have impacted the subsistence of fishermen on the Ciénaga Grande de Santa Marta, Colombia (Perdomo et al. 1998). One exceptional bloom of the toxic flagellate Chrysochromulina polylepsis killed more than 500 tons of farmed fish, valued at US \$4.5 million, along the Norwegian coast in May 1988 (Underdal et al. 1989). Loss of Pecten maximus from coastal waters of Brittany (Fig. 23a) is a loss of a national cultural heritage in France-the coquille Saint-Jacques. A complete moratorium on shellfish harvest was imposed in New Zealand because of toxic algal blooms in 1993, causing loss of export sales of NZ \$2 million a week (Chang 1994). The 1998 toxic algal bloom in coastal waters of Hong Kong and southern China caused fishery losses valued at US \$42 million. But what are the cumulative economic and social costs of anthropogenic disturbance to coastal ecosystems, and how can we quantify those losses on a global scale? Our next conceptual model will give explicit consideration to the social and economic aspects of this problem (Fig. 24).

How does nutrient enrichment, in concert with other disturbances, cause habitat changes that impact human health? Direct impacts include the estimated 300 human fatalities each year caused by consumption of shellfish contaminated with algal-derived toxins (Hallegraeff 1993). But there are probably other, indirect connections between coastal water quality and human health. A dramatic epidemic of cholera-type disease spread rapidly in 1992 from the port city of Madras to northern cities of India and all of Bangladesh, affecting thousands of people and causing many deaths on the Indian continent (Colwell 1996). The pathogenic agent, Vibrio cholerae, survives in marine and brackish waters and attaches to chitinaceous plankton such as copepods. A single copepod can carry $10^{4} \mathrm{~V}$. cholerae cells, 10 times the infectious dose for humans (Colwell 1996). Therefore, as human activities and the climate system interact to stimulate phytoplankton blooms, followed by population increases of shellfish, the potential exists for conditions that allow rapid transmission of this waterborne disease. To what extent are human alterations of the environment, such as fertilization of the coastal zone, responsible for the global resurgence of communicable diseases?

And, how do the biological changes induced by coastal fertilization propagate to other aspects of the Earth system such as atmospheric chemistry? We have identified some mechanisms: coastal phytoplankton production is a globally significant source of methyl bromide and, therefore, a contributing factor to ozone depletion (Lobert et al. 1995); some bloom-forming 
algae produce and release dimethyl sulfide (DMS) which is oxidized to sulfate in the atmosphere and contributes to acid precipitation. In summer, this biogenic emission of sulfur from the North Sea is equivalent to $16 \%$ of the anthropogenic emission of sulfur from Europe (Turner et al. 1988). Algal production of DMS is also a mode of biological climate regulation because it is the major source of cloud-condensation nuclei over the oceans and therefore exerts a strong influence on cloud cover and the Earth's radiation budget (Charlson et al. 1987). To what extent does coastal nutrient enrichment enhance this link between the biosphere and climate system, and what other modes of enrichment disturbance alter the links of ocean-atmosphere chemistry and the climate system?

Our next conceptual model (Fig. 24) will have a broader perspective that considers the social, economic and human-health costs of coastal eutrophication, and the impacts of nutrient enrichment of the Earth system at the planetary scale.

\section{(5) What synthetic tools can guide management strategies?}

The ultimate objective of all this hard work is a mechanistic understanding, based on scientific principles, from which management strategies can be designed to restore coastal ecosystem functions and biological communities that have been damaged by nutrient enrichment. Emerging principles will have practical application to solve an environmental problem that impacts the capacity of the Earth system to sustain biodiversity, water quality, and natural biogeochemical functioning in the coastal zone as it continues to be stressed by human population growth and exploitation. These impacts will expand in the developing world where most of the future increase of $\mathrm{N}$ mobilization will occur: 'much of the next round of pollution will take place in the waters of the tropics, where both the corals and the fish that inhabit these delicate ecosystems are at risk' (Nixon 1998). The effectiveness of strategies for ecosystem protection or restoration will be directly proportional to the accuracy and completeness of our conceptual model that links ecosystem responses to anthropogenic stressors. Our current level of understanding is a limitation to the development of effective management strategies. As research proceeds and our conceptual model evolves and progresses, so will the effectiveness of restoration actions.

At present, the scientific community has only a limited set of tools to help guide ecosystem management. A fundamental tool is the construction of nutrient budgets to provide the foundation for understanding the scale of human disturbance and the potential effective- ness of restoration actions for individual ecosystems. Excellent examples exist and serve as (1) templates to guide budget construction (Gordon et al. 1996), and (2) measures for comparing the nutrient status among coastal ecosystems (e.g. Nixon et al. 1996, Eyre \& Balls 1999). For example, nutrient budgets show that: the coastal ocean is a source of $\mathrm{N}$ that overwhelms all human sources to the Straits of Georgia/Juan de Fuca (Mackas \& Harrison 1997); internal recycling is the dominant source of $\mathrm{N}$ in Aarhus Bay, Denmark (Jørgensen 1996); local sources from fish farming dominate in the Archipelago Sea (Bonsdorff et al. 1997b); municipal wastewater contributes $60 \%$ of the $\mathrm{N}$ input to Long Island Sound (National Research Council 2000); riverine loading is the dominant source of nutrients to the Dutch coastal zone (De Vries et al. 1998). Among these different coastal ecosystems, there is great divergence in the scale of human disturbance of the pristine nutrient budgets. Budgets place bounds on that scale and they help us judge the potential effectiveness of actions to reduce nutrient inputs. Budget-type analyses are most valuable if they consider seasonal-scale variability: Conley (2000) suggests that reductions of $\mathrm{P}$ input to some estuaries will most directly influence the magnitude of spring primary production and subsequent oxygen consumption, whereas reductions in $\mathrm{N}$ loading will reduce phytoplankton biomass in summer and help to restore the balance between algal and vascular plant production.

As a second tool, the scientific community can develop indices to measure the sensitivity (filter efficiency) of individual ecosystems to change in nutrient inputs. Monbet's classification of estuaries by tidal amplitude (Fig. 25) could be developed into an index of the tidal component of the filter; some measures of topdown grazing (Fig. 28) could be used as an index of this biotic component of the filter. Another index compares the availability of light and nutrient resources that sustain phytoplankton growth (Fig. 30). For estuaries in which the resource index shows persistent strong light limitation (such as northern San Francisco Bay), it is unlikely that changes in nutrient input will greatly affect the growth and biomass accumulation of phytoplankton. For estuaries in which the index shows greater limitation by nutrient availability (such as Tomales Bay), it is more likely that changes in nutrient input will lead to phytoplankton responses. The index provides one measure of ecosystem sensitivity to changes in nutrient availability.

A third tool is experimentation, using representations of coastal ecosystems to measure responses to specific actions. At present, our representations are limited to mesocosms and numerical models (Nixon et al. [1986] review the rare cases of whole-ecosystem fertilization). Both have limitations, but these are 


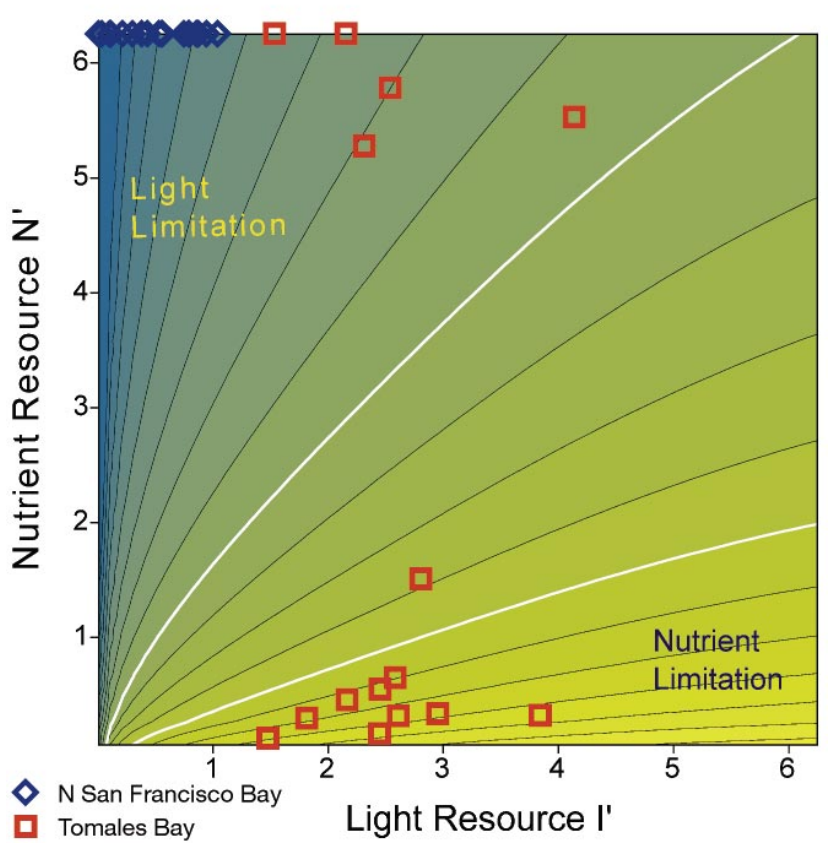

Fig. 30. Index of light vs nutrient limitation of phytoplankton growth, comparing resource distributions for a light-limited estuary (northern San Francisco Bay) and a nutrient-limited estuary (Tomales Bay, US). Redrawn from Cloern (1999), Figs. $3,5 \& 7$. Pairs of nutrient-light observations can fall into the light-limited domain (upper left), nutrient-limited domain (lower right), or in between (potential co-limitation). Measurements from annual studies show that the nutrient resource is always well above the requirements for maximum phytoplankton growth in northern San Francisco Bay, but the light resource is always limiting $(\diamond)$. Measurements from Tomales Bay show that nutrient concentrations are frequently limiting to phytoplankton growth (ㅁ). The index shows that Tomales Bay is more sensitive to change in nutrient input than northern San Francisco Bay

among the few tools available for studying the systemic responses to enrichment in the presence of filters and interactions (Fig. 24). Mesocosms designed to represent the coastal plume of the Rhine river have been used to predict how pelagic and benthic communities will respond to management plans to reduce anthropogenic nutrient loadings to the North Sea by half: experimental results suggest that nutrient reductions of this magnitude will lead to smaller spring phytoplankton blooms (including smaller Phaeocystis blooms), but perhaps have little impact on secondary production by macrozoobenthos (Prins et al. 1999). Numerical models are powerful tools because they can be built to integrate all the processes that shape ecosystem responses to nutrient change, including all components of the filter and linkages between watersheds and coastal ecosystems (Billen \& Garnier 1997). However our mathematical representations of individual processes are gross oversimplifications of complex phenomena that include feedbacks, biological behavior, complex life histories, and chaotic variabilityphenomena that are only crudely understood. Numerical models can only be useful to the extent that they are built from conceptual models that accurately and completely represent this system complexity. No models are close to real-ecosystem complexity, so modelbased predictions have inherently high uncertainty. At our present level of understanding, perhaps numerical models are most powerful as integrative tools for exploring complex system behavior and for developing general principles (e.g. Herman \& Scholten 1990, Wulf et al. 1990, Lucas et al. 1998, 1999a,b), rather than as reliable predictive tools. The challenge to build reliable predictive models will grow as we work to integrate mathematical representations of benthic and pelagic systems with models of climate, watersheds, the atmosphere, and with economic models.

Finally, the scientific community faces a challenge to find innovative ways to synthesize information from multiple sources, and then use syntheses to guide action plans. The best scientific guidance at this point will come from assessments that synthesize outputs from all the tools described above-budgets, experiments, models and simple sensitivity indices. Each tool has limitations, so the most robust assessments will be those where the application of multiple tools gives a coherent view of how a particular ecosystem responds to nutrient enrichment. Our goal of a general, globalscale understanding of coastal eutrophication will emerge as we expend greater effort at comparative analyses to understand the underlying mechanisms of ecosystem variability in the signal-response relationship. A truly global model will require more study of tropical ecosystems that may have stronger responses to the eutrophication signal than those documented in the temperate zone (Corredor et al. 1999, Downing et al. 1999). Perhaps the vision shown in Fig. 24 will be useful as a roadmap to help guide our development of that general conceptual model, and to guide the development of new tools for building restoration strategies.

Acknowledgements. Support for this review was provided by the US Geological Survey, Water Resources Division National Research Program and Toxic-Substances Hydrology Program. I thank my friends and colleagues Laurent Chauvaud, Lisa Lucas and Bill Sobczak who provided data and valuable comments on the first version of this paper.

\section{LITERATURE CITED}

Ahlgren I (1977) Role of sediments in the process of recovery of a eutrophicated lake. In: Golterman HL (ed) Interactions between sediments and freshwater. Proceedings of an international symposium, Amsterdam, 1976. Junk, The Hague, p 372-377 
Allen JR, Slinn DJ, Shammon TM, Hartnoll RG, Hawkins SJ (1998) Evidence for eutrophication of the Irish Sea over four decades. Limnol Oceanogr 43:1970-1974

Alpine AE, Cloern JE (1992) Trophic interactions and direct physical effects control phytoplankton biomass and production in an estuary. Limnol Oceanogr 37:946-955

Attrill MJ (ed) (1998) A rehabilitated estuarine ecosystem. The environment and ecology of the Thames Estuary. Kluwer Academic Publishers, Dordrecht

Bakker C, Herman PMJ, Vink M (1994) A new trend in the development of the phytoplankton in the Oosterschelde (SW Netherlands) during and after the construction of a storm-surge barrier. Hydrobiologia 282/283:79-100

Balls PW, Macdonald A, Pugh K, Edwards AC (1995) Longterm nutrient enrichment of an estuarine system: Ythan, Scotland (1958-1993). Environ Pollut 90:311-321

Bayley S, Stotts VD, Springer PF, Steenis J (1978) Changes in submerged aquatic macrophyte populations at the head of Chesapeake Bay, 1958-1975. Estuaries 1:73-84

Beukema JJ (1991) Changes in composition of bottom fauna of a tidal-flat area during a period of eutrophication. Mar Biol 111:293-301

Bianchi TS, Engelhaupt E, Westman P, Andrén T, Rolff C, Elmgren R (2000) Cyanobacterial blooms in the Baltic Sea: natural or human induced? Limnol Oceanogr 45: $716-726$

Billen G, Garnier J (1997) The Phison River plume: coastal eutrophication in response to changes in land use and water management in the watershed. Aquat Microb Ecol 13:3-17

Billen G, Garnier J, Deligne C, Billen C (1999) Estimates of early-industrial inputs to river systems: implications for coastal eutrophication. Sci Total Environ 243/244: 43-52

Bodeanu N (1993) Microalgal blooms in the Romanian area of the Black Sea and contemporary eutrophication conditions. In: Smayda TJ, Shimizu Y (eds) Toxic phytoplankton blooms in the sea. Elsevier, Amsterdam, p 203-209

Bonsdorff E, Blomqvist EM, Mattila J, Norkko A (1997a) Long-term changes and coastal eutrophication. Examples from the Åland Islands and the Archipelago Sea, northern Baltic. Oceanol Acta 20:319-329

Bonsdorff E, Blomqvist EM, Mattila J, Norkko A (1997b) Coastal eutrophication: causes, consequences and perspectives in the Archipelago areas of the northern Baltic Sea. Estuar Coast Shelf Sci 44(Suppl A):63-72

Borum J (1996) Shallow waters and land/sea boundaries. In: Jørgensen BB, Richardson K (eds) Eutrophication in coastal marine ecosystems. American Geophysical Union, Washington DC, p 179-203

Boynton WR, Garber JH, Summers R, Kemp WM (1995) Inputs, transformations, and transport of nitrogen and phosphorus in Chesapeake Bay and selected tributaries. Estuaries 18: 285-314

Boynton WR, Hagy JD, Murray L, Stokes C, Kemp WM (1996) A comparative analysis of eutrophication patterns in a temperate coastal lagoon. Estuaries 19:408-421

Breitburg D, Seitziner S, Sanders J (eds) (1999a) The effects of multiple stressors on freshwater and marine ecosystems. Limnol Oceanogr 44:739-972

Breitburg DL, Sanders JG, Gilmour CG, Hatfield CA, Osman RW, Riedel GF, Seitzinger SP, Sellner KG (1999b) Variability in responses to nutrients and trace elements, and transmission of stressor effects through an estuarine food web. Limnol Oceanogr 44:837-863

Buskey EJ, Stockwell DA (1993) Effects of a persistent 'brown tide' on zooplankton populations in the Laguna Madre of south Texas. In: Smayda TJ, Shimizu Y (eds) Toxic phytoplankton blooms in the sea. Elsevier, Amsterdam, p 659-666

Cadée GC (1984) Has input of organic matter into the western part of the Dutch Wadden Sea increased during the last decades? Neth Inst Sea Res Publ Ser 10:71-82

Cadée GC (1992) Phytoplankton variability in the Marsdiep, the Netherlands. ICES Mar Sci Symp 195:213-222

Caraco NJ, Cole J, Likens GE (1990) A comparison of phosphorus immobilization in sediments of freshwater and coastal marine systems. Biogeochemistry 9:277-290

Carlton JT, Geller JB (1993) Ecological roulette: the global transport of nonindigenous marine organisms. Science 261:78-82

Chang FH (1994) New Zealand: major shellfish poisoning (NSP) in early '93. Intergov Oceanogr Comm UNESCO, Harmful Algal News 8:1-2

Charlson RJ, Lovelock JE, Andreae MO, Warren SG (1987) Oceanic phytoplankton, atmospheric sulfur, cloud albedo and climate. Nature 326:655-661

Chauvaud L (1998) La coquille Saint-Jacques en rade de Brest: un modèle biologique d'étude des réponses de la faune benthique aux fluctuations de l'environnement. $\mathrm{PhD}$ thesis, Université de Bretagne Occidentale, Brest

Chauvaud L, Jean F, Ragueneau O, Thouzeau G (2000) Longterm variation of the Bay of Brest ecosystem: benthicpelagic coupling revisited. Mar Ecol Prog Ser 200:35-48

Christensen PB (ed) (1998) The Danish marine environment: has action improved its state? Marine research programme HAV90. Havforskning fra Miljøstyrelsen Nr. 62 Danish Environmental Protection Agency, Copenhagen

Cloern JE (1982) Does the benthos control phytoplankton biomass in South San Francisco Bay (USA)? Mar Ecol Prog Ser 9:191-202

Cloern JE (1999) The relative importance of light and nutrient limitation of phytoplankton growth: a simple index of coastal ecosystem sensitivity to nutrient enrichment. Aquat Ecol 33(1):3-15

Cohen AN, Carlton JT (1995) Nonindigenous aquatic species in a United States estuary: a case study of the biological invasions of the San Francisco Bay and Delta. A report for the US Fish and Wildlife Service and National Sea Grant College Program, Connecticut Sea Grant. US Department of Commerce, National Technical Information Service, Springfield, VA

Colwell RR (1996) Global climate and infectious disease: the cholera paradigm. Science 274:2025-2031

Conley DJ (2000) Biogeochemical nutrient cycles and nutrient management strategies. Hydrobiologia 410:87-96

Conley DJ, Schelske CL, Stoermer EF (1993) Modification of the biogeochemical cycle of silica with eutrophication. Mar Ecol Prog Ser 101:179-192

Cooper SR (1995) Chesapeake Bay watershed historical land use: impact on water quality and diatom communities. Ecol Appl 5:703-723

Cooper SR, Brush GS (1991) Long-term history of Chesapeake Bay anoxia. Science 254:992-996

Cornwell JC, Conley DJ, Owens M, Stevenson JC (1996) A sediment chronology of the eutrophication of Chesapeake Bay. Estuaries 19:488-499

Corredor JE, Howarth RW, Twilley RR, Morell JM (1999) Nitrogen cycling and anthropogenic impact in the tropical interamerican seas. Biogeochemistry 46:163-178

Costanza R and 12 others (1997) The value of the world's ecosystem services and natural capital. Nature 387: $253-260$ 
Dale B, Thorson TA, Fjellså A (1999) Dinoflagellate cysts as indicators of cultural eutrophication in the Oslofjord, Norway. Estuar Coast Shelf Sci 48:371-382

de Jonge VN (1990) Response of the Dutch Wadden Sea ecosystem to phosphorus discharges from the Rhine River. Hydrobiologia 195:49-62

de Jonge VN, Bakker JF, Van Stralen M (1996) Recent changes in the contributions of River Rhine and North Sea to the eutrophication of the western Dutch Wadden Sea. Neth J Aquat Ecol 30:27-39

D'Elia CF, Sanders JG, Boynton WR (1986) Nutrient enrichment studies in a coastal plain estuary: phytoplankton growth in large-scale, continuous cultures. Can J Fish Aquat Sci 43:397-406

De Vries I, Duin RNM, Peeters JCH, Los FJ, Bokhorst M, Laane RWPM (1998) Patterns and trends in nutrients and phytoplankton in Dutch coastal waters: comparison of time series analysis, ecological model simulation and mesocosm experiments. ICES J Mar Sci 55:620-634

Diaz RJ, Rosenberg R (1995) Marine benthic hypoxia: a review of its ecological effects and the behavioural responses of benthic macrofauna. Oceanogr Mar Biol Annu Rev 33: 245-303

Dortch Q, Whitledge TE (1992) Does nitrogen or silicon limit phytoplankton production in the Mississippi river plume and nearby regions? Cont Shelf Res 12:1293-1309

Downing JA, McClain M, Twilley R, Melack JM, Elser J, Rabalais NN, Lewis WM Jr, Turner RE, Corredor J, Soto D, Yanez-Arancibia A, Kopaska JA, Howarth RW (1999) The impact of accelerating land-use change on the $\mathrm{N}$-cycle of tropical aquatic ecosystems: current conditions and projected changes. Biogeochemistry 46:109-148

Duarte C (1995) Submerged aquatic vegetation in relation to different nutrient regimes. Ophelia 41:87-112

Dunton KH (1996) Photosynthetic production and biomass of the subtropical seagrass Halodule wrightii along an estuarine gradient. Estuaries 19:436-447

Dynesius M, Nilsson C (1994) Fragmentation and flow regulation of river systems in the northern third of the world. Science 266:753-761

Edmondson WT (1991) The uses of ecology. Lake Washington and beyond. University of Washington Press, Seattle

Eyre B (1995) A first-order nutrient budget for the tropical Moresby estuary and catchment, North Queensland, Australia. J Coast Res 11:717-732

Eyre B, Balls P (1999) A comparative study of nutrient behavior along the salinity gradient of tropical and temperate estuaries. Estuaries 22:313-326

Fjellså A, Nordberg K (1996) Toxic dinoflagellate 'blooms' in the Kattegat, North Sea, during the Holocene. Palaeogeogr Palaeoclimatol Palaeoecol 124:87-105

Fowler SW (1990) Critical review of selected heavy metal and chlorinated hydrocarbon concentrations in the marine environment. Mar Environ Res 29:1-64

Funen County Council (1991) Eutrophication of coastal waters. Coastal water quality management in the County of Funen, Denmark, 1976-1990. Funen County Council, Department of Technology and Environment, Odense

Gilbert F, Souchu P, Brianchi M, Bonin P (1997) Influence of shellfish farming activities on nitrification, nitrate reduction to ammonium and denitrification at the water-sediment interface of the Thau lagoon, France. Mar Ecol Prog Ser 151:143-153

Gordon DC Jr, Boudreau PR, Mann KH, Ong JE, Silvert WL, Smith SV, Wattayakorn G, Wulff F, Yanagi T (1996) LOICZ Biogeochemical modelling guidelines. LOICZ Reports \& studies No 5, 1-96 [http://www.nioz.nl/loicz/]
Gray JS (1992) Eutrophication in the sea. In: Colombo G, Ferrari I, Ceccherelli VU, Rossi R (eds) Marine eutrophication and population dynamics. Proc 25th Eur Mar Biol Symp. Olsen \& Olsen, Fredensborg, p 3-15

Griffiths AH (1987) Water quality of the estuary and Firth of Forth, Scotland. Proc R Soc Edinb 93:303-314

Gunnarsson JS, Sköld M (1999) Accumulation of polychlorinated biphenyls by the infaunal brittle starts Amphiura filiformis and A. chiajei: effects of eutrophication and selective feeding. Mar Ecol Prog Ser 186:173-185

Hagerman L, Josefson AB, Jensen JN (1996) In: Jørgensen BB, Richardson K (eds) Eutrophication in coastal marine ecosystems. American Geophysical Union, Washington, DC, p 155-178

Hallegraeff GM (1993) A review of harmful algal blooms and their apparent global increase. Phycologia 32:79-99

Hama J, Handa N (1994) Variability of the biomass, chemical composition and productivity of phytoplankton in Kinuura Bay, Japan during the rainy season. Estuar Coast Shelf Sci 39:497-509

Harding LW Jr, Perry ES (1997) Long-term increase of phytoplankton biomass in Chesapeake Bay, 1950-94. Mar Ecol Prog Ser 157:39-52

Hatcher A, Grant J, Schofield B (1994) Effect of suspended mussel culture (Mytilus spp.) on sedimentation, benthic respiration and sediment nutrient dynamics in a coastal bay. Mar Ecol Prog Ser 115:219-235

Hecky RE, Kilham P (1988) Nutrient limitation of phytoplankton in freshwater and marine environments: a review of recent evidence on the effects of enrichment. Limnol Oceanogr 33:796-822

Heip C (1995) Eutrophication and zoobenthos dynamics. Ophelia 41:113-136

Herman PMJ, Scholten H (1990) Can suspension-feeders stabilise estuarine ecosystems? In: Barnes M, Gibson RN (eds) Trophic relationships in the marine environment. Aberdeen University Press, Aberdeen, p 104-116

Herman PMJ, Hemminga MA, Nienhuis PH, Verschuure JM, Wessel EGJ (1996) Wax and wane of eelgrass Zostera marina and water column silica levels. Mar Ecol Prog Ser 144:303-307

Honjo T (1993) Overview on bloom dynamics and physiological ecology of Heterosigma akashiwo. In: Smayda TJ, Shimizu Y (eds) Toxic phytoplankton blooms in the sea. Elsevier, Amsterdam, p 33-41

Horstman DA (1981) Reported red-water outbreaks and their effects on fauna of the west and south coasts of South Africa, 1959-1980. Fish Bull S Afr 15:71-88

Howarth RW (1988) Nutrient limitation of net primary production in marine ecosystems. Annu Rev Ecol Syst 19: 89-110

Howarth RW, Swaney D, Marino R, Butler T, Chu CR (1995) Turbulence does not prevent nitrogen fixation by plankton in estuaries and coastal seas (reply to the comment of Paerl et al.). Limnol Oceanogr 40:639-643

Howarth RW, Chan F, Marino R (1999) Do top-down and bottom-up controls interact to exclude nitrogen-fixing cyanobacteria from the plankton of estuaries? An exploration with a simulation model. Biogeochemistry 46:203-231

Humborg C, Ittekkot V, Cociasu A, v. Bodungen B (1997) Effect of Danube River dam on Black Sea biogeochemistry and ecosystem structure. Nature 386:385-388

Humborg C, Conley DJ, Rahm L, Wulff F, Cociasu A, Ittekkot V (2000) Silicon retention in river basins: far-reaching effects on biogeochemistry and aquatic food webs in coastal marine environments. Ambio 29:45-50

Jaworski NA, Howarth RW, Hetling LJ (1997) Atmospheric 
deposition of nitrogen oxides onto the landscape contributes to coastal eutrophication in the northeast United States. Environ Sci Technol 31:1995-2004

Johansson JOR, Lewis RR III (1992) Recent improvements of water quality and biological indicators in Hillsborough Bay, a highly impacted subdivision of Tampa Bay, Florida, USA. Sci Total Environ (Suppl) 1992:1199-1215

Jørgensen BB (1996) Material flux in the sediment. In: Jørgensen BB, Richardson K (eds) Eutrophication in coastal marine ecosystems. American Geophysical Union, Washington, DC, p 115-135

Jørgensen BB, Richardson K (eds) (1996) Eutrophication in coastal marine ecosystems. Coastal and Estuarine Studies 52. American Geophysical Union, Washington, DC

Josefson AB, Rasmussen B (2000) Nutrient retention by benthic macrofaunal biomass of Danish estuaries: importance of nutrient load and residence time. Estuar Coast Shelf Sci 50:205-216

Justić D, Legović T, Rottini-Sandrini L (1987) Trends in oxygen content 1911-1984 and occurrence of benthic mortality in the northern Adriatic Sea. Estuar Coast Shelf Sci 25:435-445

Kaartvedt S, Johnsen TM, Aksnes DL, Lie U (1991). Occurrence of the toxic phytoflagellate Prymnesium parvum and associated fish mortality in a Norwegian fjord system. Can J Fish Aquat Sci 48:2316-2323

Kaas H and 10 others (1996) Danske fjorde-status over miljøtilstand, årsagssammenhœnge og udvikling. Faglig rapport fra DMU, nr. 179, Miljø- og Energiministereriet, Danmarks Miljøundersøgelser, Roskilde

Kautsky N, Kautsky H, Kautsky U, Waern M (1986) Decreased depth penetration of Fucus vesiculosus (L.) since the 1940's indicates eutrophication of the Baltic Sea. Mar Ecol Prog Ser 28:1-8

Kemp WM, Sampou P, Caffrey J, Mayer M, Henriksen K, Boynton W (1990) Ammonium recycling versus denitrification in Chesapeake Bay sediments. Limnol Oceanogr 35:1545-1563

Kideys AE (1994) Recent dramatic changes in the Black Sea ecosystem: the reason for the sharp decline in Turkish anchovy fisheries. J Mar Syst 5:171-181

Kratzer CR, Shelton JL (1998) Water quality assessment of the San Joaquin-Tulare Basins, California: analysis of available data on nutrients and suspended sediment in surface water, 1972-1990. US Geological Survey Professional Paper 1587, US Geological Survey, Reston, VA

Kronvang G, Ertebjerg G, Grant R, Kristensen P, Hovmand M, Kirkegaard J (1993) Nationwide monitoring of nutrients and their ecological effects: state of the Danish aquatic environment. Ambio 22:176-187

Kuwabara JS, Chang CCY, Cloern JE, Fries TL, Davis JA, Luoma SN (1989) Trace metal associations in the water column of South San Francisco Bay, California. Estuar Coast Shelf Sci 28:307-325

Lam CWY, Ho KC (1989) Red tides in Tolo Harbour, Hong Kong. In: Okaichi T, Anderson DM, Nemoto T (eds) Red tides: biology, environmental science and toxicology. Elsevier, New York, p 49-52

Lapointe BE (1997) Nutrient thresholds for bottom-up control of macroalgal blooms on coral reefs in Jamaica and southeast Florida. Limnol Oceanogr 42:1119-1131

Le Pape O, Del Amo Y, Ménesguen A, Aminot A, Quequiner B, Treguer P (1996) Resistance of a coastal ecosystem to increasing eutrophic conditions: the Bay of Brest (France), a semi-enclosed zone of Western Europe. Cont Shelf Res 16:1885-1907

Lobert JM, Butler JH, Montzka SA, Geller LS, Myers RC,
Elkins JW (1995) A net sink for atmospheric $\mathrm{CH}_{3} \mathrm{Br}$ in the east Pacific Ocean. Science 267:1002-1005

Lucas L, Cloern JE, Koseff JR, Monismith SG, Thompson JK (1998) Does the Sverdrup critical depth model explain bloom dynamics in estuaries? J Mar Res 56:1-41

Lucas LV, Koseff JR, Cloern JE, Monismith SG, Thompson JK (1999a) Processes governing phytoplankton blooms in estuaries. I. The local production-loss balance. Mar Ecol Prog Ser 187:1-15

Lucas LV, Koseff JR, Cloern JE, Monismith, SG, Thompson JK (1999b) Processes governing phytoplankton blooms in estuaries. II. The role of transport in global dynamics. Mar Ecol Prog Ser 187:17-30

Luoma SN, Johns C, Fisher NS, Steinberg N, Oremland RS, Reinfelder JR (1992) Determination of selenium bioavailability to a benthic bivalve from particulate and solute pathways. Environ Sci Technol 26:485-491

Luoma SN, van Geen A, Lee BG, Cloern JE (1998) Metal uptake by phytoplankton during a bloom in South San Francisco Bay: implications for metal cycling in estuaries. Limnol Oceanogr 43:1007-1016

Mackas DL, Harrison PJ (1997) Nitrogenous nutrient sources and sinks in the Juan de Fuca Strait/Strait of Georgia/ Puget Sound estuarine system: assessing the potential for eutrophication. Estuar Coast Shelf Sci 44:1-21

Maestrini Y, Granéli E (1991) Environmental conditions and ecophysiological mechanisms which led to the 1988 Chrysochromulina polylepsis bloom: an hypothesis. Oceanol Acta 14:397-413

Mailhot $\mathrm{H}$ (1987) Prediction of algal bioaccumulation and uptake rate of nine organic compounds by ten physicochemical parameters. Environ Sci Technol 21:1009-1013

Malone TC, Conley DJ, Fisher TR, Glibert PM, Harding LW, Sellner KG (1996) Scales of nutrient-limited phytoplankton productivity in Cheseapeake Bay. Estuaries 19:371-385

Margalef R (1998) Red tides and ciguatera as successful ways in the evolution and survival of an admirable old phylum. In: Reguera B, Blanco J, Fernández ML, Wyatt T (eds) Harmful algae. Xunta de Galicia Intergovernmental Oceanographic Commission of UNESCO, p 3-7

McComb AJ, Atkins RP, Birch PB, Gordon DM, Lukatelich RJ (1981) Eutrophication in the Peel-Harvey estuarine system, western Australia. In: Neilson BJ, Cronin LE (eds) Estuaries and nutrients, Humana Press, Clifton, NJ, p 323-342

Mee LD (1992) The Black Sea in crisis: a need for concerted international action. Ambio 21:278-286

Meeuwig JJ (1999) Predicting coastal eutrophication from land-use: an empirical approach to small non-stratified estuaries. Mar Ecol Prog Ser 176:231-241

Ménesguen A (1992) Modelling coastal eutrophication: the case of French Ulva mass blooms. Sci Total Environ (Suppl) 1992:979-992

Miralto A and 10 others (1999) The insidious effect of diatoms on copepod production. Nature 402:173-176

Møhlenberg F (1999) Effect of meteorology and nutrient load on oxygen depletion in a Danish micro-tidal estuary. Aquat Ecol 33:55-64

Monbet Y (1992) Control of phytoplankton biomass in estuaries: a comparative analysis of microtidal and macrotidal estuaries. Estuaries 15:563-571

Montresor M, Smetacek V (2001) The impact of harmful algal blooms in natural and human-modified systems of northern Europe. In: Wefer G, Berger W (eds) Past climate and its significance for history of NW Europe, the last 10000 years. Springer-Verlag, Heidelberg (in press)

Moreau S, Bertru G, Buson C (1998) Seasonal and spatial 
trends of nitrogen and phosphorus loads to the upper catchment of the river Vilaine (Brittany): relationships with land use. Hydrobiologia 373/374:247-258

Mosser JL, Fisher NS, Wurster CF (1972) Polychlorinated biphenyls and DDT alter species composition in mixed cultures of algae. Science 176:533-535

National Research Council (2000) Clean coastal waters: understanding and reducing the effects of nutrient pollution. National Academy Press, Washington, DC

Nehring D (1992) Eutrophication of the Baltic Sea. Sci Total Environ (Suppl) 1992:673-682

Newell RIE (1988) Ecological changes in Chesapeake Bay: are they the result of overharvesting the American oyster, Crassostrea virginica? In: Understanding the estuary. Advances in Chesapeake Bay research. US EPA CBP/TRS 24/88. CRC Publication 129. Chesapeake Bay Consortium, Solomons, MD, p 536-546

Nichols FH, Cloern JE, Luoma SN, Peterson DH (1986) The modification of an estuary. Science 231:567-573

Nixon SW (1992) Quantifying the relationship between nitrogen input and the productivity of marine ecosystems. In: Takahashi M, Nakata K, Parsons TR (eds) Proceedings of Advanced Marine Technology Conference, Vol 5, Tokyo, p 57-83

Nixon SW (1995) Coastal marine eutrophication: a definition, social causes, and future concerns. Ophelia 41:199-219

Nixon SW (1998) Enriching the sea to death. Sci Am 9(3): 48-53

Nixon SW, Oviatt CA, Frithsen J, Sullivan B (1986) Nutrients and the productivity of estuarine and coastal marine ecosystems. J Limnol Soc S Afr 12:43-71

Nixon SW and 15 others (1996) The fate of nitrogen and phosphorus at the land-sea margin of the North Atlantic Ocean. Biogeochemistry 35:141-180

Officer CB, Ryther JH (1980) The possible importance of silicon in marine eutrophication. Mar Ecol Prog Ser 3:83-91

Orth RJ, Moore KA (1983) Chesapeake Bay: an unprecedented decline in submerged aquatic vegetation. Science 222:51-52

Oviatt CA, Keller AA, Sampou PA, Beatty LL (1986) Patterns of productivity during eutrophication: a mesocosm experiment. Mar Ecol Prog Ser 28:69-80

Oviatt C, Doering P, Nowicki B, Reed L, Cole J, Frithsen J (1995) An ecosystem level experiment on nutrient limitation in temperate coastal marine environments. Mar Ecol Prog Ser 116:171-179

Paerl HW, Rudek J, Mallin MA (1990) Stimulation of phytoplankton production in coastal waters by natural rainfall inputs: nutritional and trophic implications. Mar Biol 107: 247-254

Paerl HW, Pinckney JL, Kucera SA (1995) Clarification of the structural and functional roles of heterocysts and anoxic microzones in the control of pelagic nitrogen fixation. Limnol Oceanogr 40:634-638

Paerl HW, Pinckney JL, Fear JM, Peierls BL (1998) Ecosystem responses to internal and watershed organic matter loading: consequences for hypoxia in the eutrophying Neuse River Estuary, North Carolina, USA. Mar Ecol Prog Ser 166:17-25

Pearson TH, Rosenberg R (1978) Macrobenthic succession in relation to organic enrichment and pollution of the marine environment. Oceanogr Mar Biol Annu Rev 16:229-311

Perdomo L, Ensminger I, Espinosa LF, Elster C, WallnerKersanach M, Schnetter ML (1998) The mangrove ecosystem of the Ciénaga Grande de Santa Marta (Colombia): observations on regeneration and trace metals in sediment. Mar Pollut Bull 37:393-403
Peterson DH, Schemel LE, Smith RE, Harmon DD, Hager SW (1987) The flux of particulate organic carbon in estuaries: Phytoplankton productivity and oxygen consumption. US Geological Survey Water Supply Series, Selected Papers in the Hydrologic Sciences, Reston, VA, p 41-49

Philippart CJM, Cadée GC, van Raaphorst W, Riegman R (2000) Long-term phytoplankton-nutrient interactions in a shallow coastal sea: algal community structure, nutrient budgets, and denitrification potential. Limnol Oceanogr 45:131-144

Pihl L (1994) Changes in the diet of demersal fish due to eutrophication-induced hypoxia in the Kattegat, Sweden. Can J Fish Aquat Sci 51:321-336

Poulet SA, Ianora A, Miralto A, Meijer L (1994) Do diatoms arrest embryonic development in copepods? Mar Ecol Prog Ser 111:79-86

Prins TC, Escaravage V, Wetsteyn LPMJ, Peeters JCH, Smaal AC (1999) Effects of different N- and P-loading on primary and secondary production in an experimental marine ecosystem. Aquat Ecol 33:65-81

Puckett LJ (1995) Identifying the major sources of nutrient water pollution. Environ Sci Technol 29:408A-414A

Rabalais NN, Turner RE, Justić D, Dortch Q, Wiseman WJ Jr, Sen Gupta BK (1996) Nutrient changes in the Mississippi River and system responses on the adjacent continental shelf. Estuaries 19:386-407

Radach G, Berg J, Hagmeier E (1990) Long-term changes of the annual cycles of meteorological, hydrographic, nutrient and phytoplankton time series at Helgoland and at LV ELBE 1 in the German Bight. Cont Shelf Res 10:305-328

Raffaelli DG, Raven JA, Poole LJ (1998) Ecological impacts of green macroalgal blooms. Oceanogr Mar Biol Annu Rev 36:97-125

Rask N, Pedersen ST, Jensen MH (1999) Response to lowered nutrient discharges in the coastal waters around the island of Funen, Denmark. Hydrobiologia 393:69-81

Redfield AC, Ketchum BH, Richards FA (1963) The influence of organisms on the composition of sea-water. In: Hill MN (ed) The sea, Vol 2. The composition of sea-water comparative and descriptive oceanography. Interscience Publishers, New York, p 26-77

Reinfelder JR, Fisher NS (1991) The assimilation of elements ingested by marine copepods. Science 251:794-796

Relexans JC, Meybeck M, Billen G, Brugeaille M, Etcheber H, Somville M (1988) Algal and microbial processes involved in particulate organic matter dynamics in the Loire Estuary. Estuar Coast Shelf Sci 27:625-644

Richardson K (1996) Carbon flow in the water column. Case study: southern Kattegat. In: Jørgensen BB, Richardson K (eds) Eutrophication in coastal marine ecosystems. American Geophysical Union, Washington, DC, p 179-203

Richardson K (1997) Harmful or exceptional phytoplankton blooms in the marine ecosystem. Adv Mar Biol 31:301-385

Riegman R, Noordeloos AAM, Cadée GC (1992) Phaeocystis blooms and eutrophication of the continental coastal zones of the North Sea. Mar Biol 112:479-484

Riegman R, Rowe A, Noordeloos AAM, Cadée GC (1993) Evidence for eutrophication induced Phaeocystis sp. blooms in the Marsdiep area (the Netherlands). In: Smayda TJ, Shimizu Y (eds) Toxic phytoplankton blooms in the sea. Elsevier, Amsterdam, p 799-805

Rosenberg R (1990) Negative oxygen trends in Swedish coastal bottom waters. Mar Pollut Bull 21:335-339

Rosenberg R, Gray JS, Josefson AB, Pearson TH (1987) Petersen's benthic stations revisited. II. Is the Oslofjord and eastern Skagerrak enriched? J Exp Mar Biol Ecol 105: 219-251 
Rossignol-Strick M (1985) A marine anoxic event on the Brittany coast, July 1982. J Coast Res 1:11-20

Rothschild BJ, Ault JS, Goulletquer P, Heral M (1994) Decline of the Chesapeake Bay oyster populations: a century of habitat destruction and overfishing. Mar Ecol Prog Ser 111:29-39

Rydberg L, Edler L, Floderus S, Granéli W (1991) Interaction between supply of nutrients, primary production, sedimentation and oxygen consumption in the SE Kattegat. Ambio 14:134-141

Sandén P, Håkansson B (1996) Long-term trends in Secchi depth in the Baltic Sea. Limnol Oceanogr 41:346-351

Sanders JG, Cibik SJ (1988) Response of Chesapeake Bay phytoplankton communities to low levels of toxic substances. Mar Pollut Bull 19:439-444

Sanders JG, Riedel GR (1993) Trace element transformation during the development of an estuarine algal bloom. Estuaries 16:521-532

Schelske CL, Stoermer EF (1971) Eutrophication, silica depletion, and predicted changes in algal quality in Lake Michigan. Science 173:423-424

Schindler DW (1981) Studies of eutrophication in lakes and their relevance to the estuarine environment. In: Neilson BJ, Cronin LE (eds) Estuaries and nutrients. Humana Press, Clifton, NJ, p 371-82

Schindler DW (1987) Detecting ecosystem responses to anthropogenic stress. Can J Fish Aquat Sci 44(Suppl) $1: 6-25$

Sellner KG, Olson MM, Olli K (1996) Copepod interactions with toxic and non-toxic cyanobacteria from the Gulf of Finland. Phycologia 35:177-182

Sfriso A, Marcomini A, Pavoni B, Orio AA (1993) Species composition, biomass, and net primary production in shallow coastal waters: the Venice Lagoon. Bioresource Technol $44: 235-250$

Smayda TJ (1989) Primary production and the global epidemic of phytoplankton blooms in the sea: a linkage? In: Cosper EM, Bricelj VM, Carpenter EJ (eds) Novel phytoplankton blooms. Springer-Verlag, Berlin, p 449-483

Smetacek V, Bathmann U, Nöthig EM, Scharek R (1991) Coastal eutrophication: causes and consequences. In: Mantoura RFC, Martin JM, Wollast R (eds) Ocean margin processes in global change. John Wiley and Sons, New York, p 251-279

Smit H, van de Velde G, Smits R, Coops H (1997) Ecosystem responses in the Rhine-Meuse Delta during two decades after enclosure and steps toward estuary restoration. Estuaries 20:504-520

Smith DE, Leffler M, Mackiernan G (eds) (1992) Oxygen dynamics in the Chesapeake Bay. A synthesis of recent research. Maryland Sea Grant, College Park

Smith SV (1984) Phosphorus versus nitrogen limitation in the marine environment. Limnol Oceanogr 29:1149-1160

Šolić M, Krstulović N, Marasović I, Baranović A, Pucher-

Editorial responsibility: Otto Kinne (Editor),

Oldendorf/Luhe, Germany
Petković T, Vučetić T (1997) Analysis of time series of planktonic communities in the Adriatic Sea: distinguishing between natural and man-induced changes. Oceanol Acta 20:131-143

Stange K, Swackhamer DL (1994) Factors affecting phytoplankton species-specific differences in accumulation of 40 polychlorinated biphenyls (PCBs). Environ Toxicol Chem 13:1849-1860

Turner SM, Malin G, Liss PS, Harbour DS, Holligan PM (1988) The seasonal variation of dimethyl sulfide and dimethylsulfoniopropionate concentrations in nearshore waters. Limnol Oceanogr 33:364-375

Underdal B, Skulberg OM, Dahl E, Aune T (1989) Disastrous bloom of Chrysochromulina polylepsis (Prymnesiophyceae) in Norwegian coastal waters 1988-mortality in marine biota. Ambio 18:265-270

Valiela I and 11 others (1992) Couplings of watersheds and coastal waters: sources and consequences of nutrient enrichment in Waquoit Bay, Massachusetts. Estuaries 15: 443-457

Valiela I, McClelland J, Hauxwell J, Behr PJ, Hersh D, Foreman K (1997) Macroalgal blooms in shallow estuaries: controls and ecophysiological and ecosystem consequences. Limnol Oceanogr 42:1105-1118

van Katwijk, MM, Vergeer LHT, Schmitz GHW, Roelofs JGM (1997) Ammonium toxicity in eelgrass Zostera marina. Mar Ecol Prog Ser 157:159-173

Vieira MEC, Chant R (1993) On the contribution of subtidal volume fluxes to algal blooms in Long Island estuaries. Estuar Coast Shelf Sci 36:15-29

Vitousek PM, Mooney HA, Lubchenco J, Melillo JM (1997) Human domination of Earth's ecosystems. Science 277: 494-499

Vollenweider RA (1976) Advances in defining critical loading levels of phosphorus in lake eutrophication. Mem Ist Ital Idrobiol 33:53-83

Vollenweider RA (1992) Coastal marine eutrophication: principles and control. Sci Total Environ (Suppl) 1992:1-21

Weaver MJ, Magnuson JJ, Clayton MK (1997) Distribution of littoral fishes in structurally complex macrophytes. Can J Fish Aquat Sci 54:2277-2289

Wulff F, Stigebrandt A, Rahm L (1990) Nutrient dynamics of the Baltic Sea. Ambio 19:126-133

Yin K, Harrison PJ, Chen J, Huang W, Qian PY (1999) Red tides during spring 1998 in Hong Kong: is El Niño responsible? Mar Ecol Prog Ser 187:289-294

Zimmerman AR, Canuel EA (2000) A geochemical record of eutrophication and anoxia in Chesapeake Bay sediments: anthropogenic influence on organic matter composition. Mar Chem 69:117-137

Zingone A, Casotti R, d'Alcalà MR, Scardi M, Marino D (1995) 'St Martin's Summer': the case of an autumn phytoplankton bloom in the Gulf of Naples (Mediterranean Sea) J Plankton Res 17:575-593

Submitted: April 3, 2000; Accepted: July 25, 2000

Proofs received from author(s): December 29, 2000 